NBER WORKING PAPER SERIES

\title{
PERSONNEL ECONOMICS
}

Edward P. Lazear

Paul Oyer

Working Paper 13480

http://www.nber.org/papers/w13480

\section{NATIONAL BUREAU OF ECONOMIC RESEARCH \\ 1050 Massachusetts Avenue \\ Cambridge, MA 02138 \\ October 2007}

We thank the editors, James Malcomson, Bentley MacLeod, Scott Schaefer, Jan Zabojnik, and participants in the Handbook conference at Stanford for comments. This is a draft of a chapter to appear in the forthcoming Handbook of Organizational Economics, edited by Robert Gibbons and D. John Roberts and published by Princeton University Press. The views expressed herein are those of the author(s) and do not necessarily reflect the views of the National Bureau of Economic Research.

(C) 2007 by Edward P. Lazear and Paul Oyer. All rights reserved. Short sections of text, not to exceed two paragraphs, may be quoted without explicit permission provided that full credit, including (C notice, is given to the source. 
Personnel Economics

Edward P. Lazear and Paul Oyer

NBER Working Paper No. 13480

October 2007

JEL No. J3,J41,M5

\begin{abstract}
$\underline{\text { ABSTRACT }}$
In this review of the personnel economics literature, we introduce key topics of personnel economics, focus on some relatively new findings that have emerged since prior reviews of some or all of the personnel economics literature, and suggest open questions in personnel economics where future research can make valuable contributions to the literature. We explore five aspects of the employment relationship - incentives, matching firms with workers, compensation, skill development, and the organization of work - reviewing the main theories, empirical tests of those theories, and the open questions in each area.
\end{abstract}

Edward P. Lazear

Graduate School of Business

Stanford University

Stanford, CA 94305-5015

and NBER

lazear@gsb.stanford.edu

Paul Oyer

Graduate School of Business

Stanford University

518 Memorial Way

Stanford, CA 94305-5015

and NBER

pauloyer@stanford.edu 


\section{Introduction}

Personnel economics is the application of economic and mathematical approaches to traditional topics in the study of human resource management. This includes topics such as compensation, turnover, and incentives that are inherently economic, as well as those that do not at first appear to be economic topics (such as norms, teamwork, worker empowerment, and peer relationships.) Using the tools from advances in game theory, information economics, econometrics, and other areas of economics, personnel economics has come a long way over the last few decades. It now produces a large share of the labor economics literature, has earned its own code in the Journal of Economic Literature classification system (M5), and has its own working group within the National Bureau of Economic Research. In this paper, we review how this literature has developed and discuss some avenues for fruitful future research.

Personnel economics provides both positive and normative analysis of human resources practices and methods. On the positive/descriptive side, we study a range of questions. When do firms choose to use one form of compensation over another? When are teams important? How do firms find the right workers? When are certain benefits or stock grants given to workers? The list extends to any decision an employer has to make with respect to its dealings with employees. That is, personnel economics attempts to describe how human resource practices can best address an employer's goals, subject to the constraint that employee actions will be affected by those practices.

Perhaps because the subject was taken up by business school economists whose job it is to teach managers what to do, personnel economics has not shied away from being somewhat prescriptive. Several MBA textbooks and numerous MBA classes that are either focused on personnel economics or cover it as part of a broader subject deliver research findings to current and future managers. ${ }^{1}$ In many ways, the basic outlines and topics of this chapter are similar to the syllabi for the MBA classes we teach at Stanford (though the details are surely very different.) Given the importance of human resources to many organizations' success and the fact that labor accounts for the majority of business costs, bringing research findings to managers can have an important effect.

\footnotetext{
${ }^{1}$ A recent paper by Bloom and Van Reenan (2007) suggests that managers can benefit from using "modern" managerial practices, including some specific practices studied in personnel economics.
} 
In this review, we will introduce the key topics of personnel economics. We will also focus on some relatively new findings that have emerged since prior reviews of some or all of the personnel economics literature, such as Gibbons and Waldman (1999), Malcomson (1999), Prendergast (1999), Murphy (1999), and Lazear (1999, 2000b). Throughout the discussion and in the conclusion, we will suggest open questions where future research can make valuable contributions to the literature.

Personnel economics research has focused on five aspects of employment relationships incentives, matching firms with workers, compensation, skill development, and the organization of work. Though some research focuses on only one of these, much of the literature touches on multiple parts of jobs. For example, incentives have an effect on which workers accept positions and the organization of the workplace depends on the skills a firm develops (or selects for). Nonetheless, these five areas of employment relationships allow for a broad categorization of research in personnel economics. So we explore each of these in turn, reviewing the main theories, empirical tests of those theories, and the open questions in each area.

Before going on, it is worth briefly noting what personal economics is not. Personnel economics is a branch of labor economics, but there is a great deal of labor economics that is not personnel economics. Studies that do not consider interactions between a firm and workers or do not explicitly or implicitly consider a firm trying to maximize some objective (usually profits) are not personnel economics. Many findings in labor economics are important conceptual or empirical inputs to, but not part of, personnel economics. For example, labor economists estimate Mincer-ian earnings functions of the returns to experience and the return to schooling and they estimate labor supply functions. While these equilibrium outcomes are very important issues to firms designing personnel policies, they are not strategic choices of the firm. Similarly, most personnel economics is not policy-oriented. Personnel economics models typically focus on welfare within a given employment relationship rather than on overall social welfare function. In the absence of a market failure, firms' best interests will be the same as those of the economy as a whole. While there are some exceptions (for example, policy and personnel economics influence one another in the study of workplace discrimination), the main contributions of personnel economics to social welfare are in research advances and helping managers to run their businesses more efficiently rather than in influencing policymakers' decisions. 


\section{Incentives}

Firms and employees naturally have opposing interests in that employee effort typically leads to benefits to the firm and costs to the employee. However, there can be gains from trade if the value to employers is enough to compensate workers for the cost of their effort. Encouraging employee effort is a central issue in personnel economics and, as with much of economics, has led to a large literature on incentives. When effort is contractible, providing efficient incentives is trivial. But, in the more realistic case where there is hidden action (moral hazard), one of the keys to successful personnel practices is to design incentives for employees.

When effort is not contractible, one potential way (though not the only way) to get the socially efficient level of worker effort is to pay the worker the full value of output - that is, sell the firm to the worker. The firm could set a base salary to meet the worker's participation constraint and let the worker keep all the marginal fruits of his effort. The base salary will need to be negative - that is, the worker will pay the firm for the right to work there - in order for the firm to find the employment arrangement profitable. In other words, moral hazard problems can be solved by making employees the residual claimants on their effort. If individuals own all their output, they will efficiently match the marginal benefits of their effort to the marginal cost.

There are employment arrangements that involve selling the firm to the worker (such as taxi drivers who rent cabs for a shift and keep all fares), but these jobs are exceptions. Why does this simple model fail for the vast majority of workers who have positive base wages and piece rates of less than one (and usually zero)? There are many reasons, but they generally relate to the facts that worker output (that is, measures of the worker's productivity) is usually imperfectly related to inputs (that is, the worker's effort), that firms cannot always credibly commit to reward effort ex post, and that individuals are typically more risk averse than employers.

\subsubsection{The Trade-Off Between Risk and Incentives}


Most theoretical principal-agent models assume that output is an increasing function of effort and it is also influenced by some unobservable random shock. ${ }^{2}$ The employee's utility is decreasing and concave in effort (that is, his disutility of effort is positive and convex.) Because he is risk averse, utility is increasing and concave in income. The complication, which makes it impossible to simply pay the agent for his inputs, is that the principal can only observe the output measure, so this is the only variable upon which compensation contracts can be based. If the two parties could write enforceable contracts based on effort, the problem would be simple. The risk neutral firm would simply pay for effort and the agent would be completely insured.

The problem for the principal is to set the compensation scheme to maximize profit subject to incentive compatibility and participation constraints. A key implication is that there is now a tradeoff between insurance and incentives. Because workers do not like risk, the firm must dampen the relation of wages to output. If compensation is based largely on output, the firm may have to provide substantial risk compensation. But if compensation is not based on output, workers will put forth little effort. The second-best solution, though the "best" compromise, forces the worker to bear risk and provides the firm with an inefficient amount of effort.

This model has two key predictions. First, the stronger the incentives, the harder the employee will work. As we will discuss below, there is ample empirical evidence to suggest that this relationship holds in most employment relationships. Second, there is a trade-off between risk and incentives. Everything else equal, in settings where factors beyond the employee's control have a relatively large effect on output, incentives will be weaker. As we also discuss below, probably at least partially due to an inability to make "everything else equal", the empirical evidence on this is decidedly mixed.

\subsubsection{Distortions in Performance Measures}

Imperfections with performance measurement can lead firms to limit the use of incentives even when employees are risk neutral. In addition to exogenous shocks to output measures, the usefulness of a performance measure may also be limited by employees having private

\footnotetext{
${ }^{2}$ See Prendergast (1999) for a somewhat more detailed description of moral hazard theory. See Johnson (1950) and Cheung (1969) for important early compensation analyses from the agricultural economics literature and Ross (1973), Mirrlees (1974), Stiglitz (1975), Bergson (1978), and Holmstrom (1979) for early modern treatments of the moral hazard problem.
} 
information or their ability to influence the measure without actually advancing the principal's goals.

Gibbons (1987) considers the case where only the worker knows the difficulty of the job and only the worker knows his true action. Under these circumstances, Gibbons shows that workers will restrict output (that is, there will be a "ratchet effect") when the firm cannot commit not to use information it learns about the difficulty of the task. He argues that this contributed to the decline of piece rate systems which were extensively used at the end of the $19^{\text {th }}$ century.

Another class of models considers the implications of employees that can affect the output measure differently from their effect on actual output. Lazear (1986a) briefly discussed the implications for incentives and performance measurement when workers can increase quantity at the expense of quality. Baker (1992) provides a more general model of a firm that wants to maximize some non-contractible objective (call it $V$ ). The firm can write compensation contracts based on $P$, which is imperfectly correlated with $V$. The employee has private information about how his actions affect both $P$ and $V$. The firm wants to provide incentives so that the employee will exert more effort, but has to trade this off against the fact that the employee may exert effort when that effort has a large effect on $P$ but not $V$. That is, the firm has to worry about the fact that incentives drive efficient effort and "gaming" at the same time.

Holmstrom and Milgrom (1991) explore the limits of measurement from a slightly different perspective. They derive a "multi-tasking" model where an employee engages in two tasks that affect actual output and measured output differently. Incentive contracts may drive the employee to under-invest or over-invest in one or both tasks. They discuss how this may explain the limits of incentive pay for teachers. While incentives may lead teachers to work harder, they may also focus their effort on teaching rote skills that are rewarded on standardized tests at the expense of teaching logical reasoning and other skills where the payoff is not easily measured in the short-term. ${ }^{3}$ As we discuss below, these models are generally consistent with several empirical studies showing unintended responses to incentives. ${ }^{4}$

\subsubsection{Subjective Measures of Performance}

\footnotetext{
${ }^{3}$ Lazear (2006) lays out how the performance measures should be designed and how much information about them should be given to employees when employees engage in multiple tasks.

${ }^{4}$ One case study that shows direct evidence of the importance of multi-task issues is Brickley and Zimmerman (2001). They show that teacher ratings rose and research output fell at the University of Rochester's Simon School of Business after the administration increased the relative importance of teaching in its reward structure.
} 
Given the limits of objective performance measures, what alternatives do firms have for motivating workers? The answer for most employees is various incentives based on subjective measures of performance. That is, the performance of most employees is monitored by some supervisor(s) that gets a reasonably accurate, but non-verifiable, signal of how good a job that employee does. Good performance can then be rewarded through a variety of mechanisms, including increases in base salary, subjectively determined bonus payments, or promotions.

Baker, Gibbons, and Murphy (1994), Bull (1987), and MacLeod and Malcomson (1989), model the use of subjective performance evaluation. They analyze the optimal mix of incentives based on imperfect objective measures and perfect (but unverifiable) subjective measures. These models highlight the trade-off between strong incentives from well-designed subjective measures versus the fact that employees have to trust firms to follow through on the inherently implicit contracts involved in any non-verifiable performance measure. For example, many Wall Street firms distribute year-end bonuses to employees based on largely subjective measures of the individuals' contributions. The shareholders of those firms would gain in the short-term by announcing that nobody had earned any bonus in a given year, but the firm would find it hard to motivate employees in the future.

As the pioneering career concerns models of Fama (1980) and Holmstrom (1999) discuss, immediate pay-for-performance is not necessary if current performance affects an employee's reputation and future compensation. ${ }^{5}$ Gibbons and Murphy (1992), building on these models, analyze employees that exert effort both in response to explicit incentives and in the hopes of improving employers' beliefs about their ability. Firms do not need to provide strong current-period incentives for young workers, who have more reason to be motivated by future promotions and opportunities. They find some support for the model in the way Chief Executive Officer compensation varies with age and experience. Chevalier and Ellison (1999), who study mutual fund managers, find further support for age-based variation in the need for objective incentives.

In addition to the limits that come with using implicit contracts for enforcement, subjective performance evaluation also is limited by differences between actual and measured performance. There are interesting models of at least three ways that subjective assessments can

\footnotetext{
${ }^{5}$ See Prendergast (1999) and Gibbons and Waldman (1999) for more detail on career concerns models.
} 
differ from actual productivity. First, employees can take actions that affect their supervisors' assessments. This issue has been studied in a series of papers on "influence activity" starting with Milgrom and Roberts (1988). The key idea is that employees will try to influence their bosses' decisions in their favor (and not necessarily in the interests of the firm) if their pay does not properly reflect their productivity. Firms face a trade-off between taking advantage of the manager's information and letting the manager manipulate decisions in her own best interests. For decisions that do not affect the distribution of benefits within the firm, this presents no problem. But when decisions have distributional implications, the firm may want to commit not to use information provided by agents. Meyer, Milgrom, and Roberts (1992) and Schaefer (1998) show how the firm can benefit from a crisis (that is, very bad alternatives for agents) in order to reduce influence activity and align the interests of employees and the firm. ${ }^{6}$

Second, Prendergast and Topel (1996) consider a manager that favors some workers over others. That is, the manager affects the payoffs of the employees and the distribution of employee payoffs, in turn, affects the utility of the manager. The firm has to trade off the informational advantage of the manager regarding the employees' true performance, the taste for the manager to have more discretion, and the distortion to incentives caused by favoritism. Favoritism leads the firm to reduce incentives and to rely on imperfect (but non-corruptible) objective performance measures.

Finally, MacLeod (2003) considers the optimal contract when the manager and employee have different opinions about the employee's performance. He shows how the optimal implicit contract will vary with the degree of correlation between the manager's assessment of the employee's performance and the employee's self-assessment. The model predicts the tendency of managers to bunch or compress employee's ratings. MacLeod (2003) also studies the effects of favoritism, allowing for a more general set of contracts than Prendergast and Topel (1996) study. He shows that favoritism reduces the incentives of employees that are discriminated against, leading pay to suffer both due to discrimination and lower effort. This has the interesting implication that, holding performance constant, measured differences in wages will understate the importance of manager bias because it will ignore the effect on the employees' incentives.

\footnotetext{
${ }^{6}$ Also see Fairburn and Malcomson (2001), who develop an integrated model of incentives and promotions when managers can engage in influence activity. They argue that managers with sufficient monetary incentives will be resistant to influence activity when making promotion decisions, which both makes promotion-based incentives stronger and more efficiently matches workers to appropriate jobs.
} 
These models of subjective performance evaluation and implicit contracts have made important contributions to personnel economics and our understanding of compensation structure. However, while these models are consistent with anecdotal examples and case studies, they have not been backed up by a great deal of rigorous empirical corroboration. Hayes and Schaefer (2000) provide compelling (though indirect) evidence on the importance of implicit contracts and subjective performance evaluation of executives. They argue that a board of directors that uses subjective evaluation will reward executives in the current period for actions that will affect objective measures of performance in future periods. They then show that there is an important empirical relationship between current pay and future performance and that this relationship is stronger at firms where they would expect subjective performance measures to be relatively advantageous for providing efficient incentives.

\subsubsection{Relative Performance Evaluation}

Some performance measures, whether objective or subjective, can be improved by making them depend on an employee's relative performance rather than some absolute standard. Relative performance evaluation (RPE) can be used in two different ways. First, firms can use the performance of a peer group of competitors to filter out shocks that are common to the whole peer group. This helps the firm to lower the risk (and the associated compensation premium) imposed on individual employees. As Gibbons and Murphy (1991) and Antle and Smith (1986) discuss, this idea has the empirical implication that pay will be increasing in the employee's own performance but decreasing in the average performance of the reference group. As we discuss below in Section 4.3, at least in the case of Chief Executive Officers (where their performance and that of a peer group are easily observed), there is surprisingly little support for filtering out common shocks of a peer group.

A second form of RPE is to use fixed rewards for a fixed group of people where the distribution of rewards is based on the order of the participants' performance. This form of reward system, generally known as a tournament, can vary from a group of people competing for a single promotion (such as to CEO) to a large set of prizes that diminish in value as a person's relative performance gets lower (such as at a golf tournament or in the memorable real estate sales tournament in the drama Glengarry Glen Ross.) 
Tournament theory, as modeled by Lazear and Rosen (1981), models promotions as a relative game. The compensation at one level of the firm, in addition to motivating individuals at that level, motivates those at lower levels. There are three basic principles of tournament theory. First, prizes are fixed in advance and depend on relative rather than absolute performance. Second, larger spreads in wages at different levels of the hierarchy motivate those at lower levels to put forth more effort. Third, there is an optimal spread. Although a greater spread increases effort, at some point the additional wages necessary to compensate workers for the increased effort is larger than the additional output generated.

An important variable in the Lazear and Rosen (1981) model is the amount of noise - that is, to what degree luck affects the probability of winning. When there is more noise (so that luck becomes relatively more important and effort relatively less important), workers will try less hard to win because effort has a smaller effect on whether or not they win. In production environments that are very uncertain, large raises must be given in order to offset the tendency by workers to reduce effort. Similarly, the number of slots available affects effort. If a firm has 100 vice-presidents and only one slot for president, most VPs will give up trying to become president thinking that the chance of promotion is too slim. At the other extreme, if there were 100 VP slots and 100 president slots so that every VP knew that she would be promoted to president, VPs would become complacent.

The firm can use the size of the spread between pay at various levels to manage effort. When luck is unimportant, the wage spread will be small. But when luck is important, the firm needs to increase the spread to increase effort. This may help explain differences in salary structure across countries or across industries. Lazear and Rosen's (1981) model implies that riskier industries (where this is interpreted as risk that affects individual output) should have larger wage spreads than less risky industries to induce workers to put forth the appropriate amount of effort. ${ }^{7}$

These basic ideas of tournament theory have been extended in numerous ways. For example, while Lazear and Rosen (1981) focus on relative performance strictly as a means of generating incentives, Green and Stokey (1983) highlight the potential usefulness of tournaments in removing common shocks from risky performance measures. They show how individual incentive contracts compare to tournaments based on variation in how common the shocks to

\footnotetext{
${ }^{7}$ This prediction also comes from incentive models where agents are risk averse.
} 
agent output are, how easily the firm can observe these shocks, and how many employees participate in the tournament. Nalebuff and Stiglitz (1983) allow for risk-averse employees, allow the number of participants in the contest to vary, and allow for both rewards and penalties. They derive a large set of results regarding when tournaments will be more efficient than incentive schemes that are not based on relative performance and how the optimal incentive system will vary with the number of participants, environmental uncertainty, and other factors.

Dye (1984) and Lazear (1989) consider how the potential for collusion, sabotage, or other forms of non-cooperative behavior in tournaments counter the incentive value of a large spread in rewards. Chan (1995) considers how firms should balance the incentive value of internal promotion tournaments against the value of retaining the option to hire an outsider when a senior opening occurs. In the basic Lazear and Rosen (1981) framework, firms can consider outsiders and keep tournament incentives strong by increasing the rewards for being promoted. However, this can cause problems such as influence activity or sabotage. Chan (1995) shows that a potentially useful alternative is to give insiders a handicap in the tournament.

Patterns of pay and promotions within firms and in other contest contexts fit the predictions of tournament theory. Devaro (2006) uses a sample of recent hires and their initial promotions to fit a structural model of tournaments. He shows the importance of relative, rather than absolute performance in determining promotions. Knoeber and Thurman (1994) provide empirical evidence consistent with several specific predictions of tournament theory in the context of rewards for producers of broiler chickens. They show, for example, that spreads between prize values affect output. Drago and Garvey (1998), using a survey of Australian firms, show that individuals are less helpful and work harder when promotion incentives are strong. Ehrenberg and Bognanno (1990) show that golfers are affected by prize spreads in tournaments. Finally, Bull, Schotter, and Weigelt (1987) do laboratory experiments on how people respond to contests with piece rates and tournaments, so "effort" is chosen and stated. The results of their experiments are generally supportive of tournament theory, though they find that less able people expend more effort than the theory would predict.

\subsubsection{Alternative to Incentives I - Monitoring}


An alternative to financial incentives is to simply monitor workers. If a supervisor can keep close watch over employees, she can insure that the employee takes the best action. However, monitoring is typically imperfect, which led to the idea of efficiency wages. Shapiro and Stiglitz (1984) suggest that a firm will pay workers a wage premium when it cannot perfectly monitor effort. Workers, facing a choice between earning this wage premium if they work hard and facing a probabilistic chance of being caught and fired if they shirk, choose to work hard.

Efficiency wage theory implies a negative relationship between monitoring intensity and wages. ${ }^{8}$ The empirical evidence in favor of this prediction is mixed, at best. ${ }^{9}$ This may be because the conditions that make efficiency wages optimal for individual employers may not exist at a large subset of firms in the economy. That is, there could well be many firms that can monitor very effectively or use output-based incentives, while other firms (such as the one studied by Cappelli and Chauvin, 1991) use efficiency wages.

A recent study by Nagin, Rebitzer, Sanders, and Taylor (2002), while not directly testing the relevance of efficiency wage theory, finds empirical support for the underlying relationship between employee productivity and the probability of catching employees that do not act in the firm's best interests. They run a field experiment at a telephone solicitation company where employees spend their workdays calling people to ask for donations to charitable organizations. They find that the rate at which workers "cheat" by trying to get paid for donations people did not actually make varies in the opposite direction of the rate at which managers audit donations. When the probability of getting caught goes up, workers cheat less. ${ }^{10}$ However, based on a survey of the telephone solicitors, Nagin et al (2002) conclude there is little evidence to support another key idea in efficiency wage models - that those workers who value a job the most will react the most to monitoring.

\subsubsection{Alternative to Incentives II - Intrinsic Rewards}

\footnotetext{
${ }^{8}$ The monitoring/pay relationship is the primary implication for the personnel economics literature. But Shapiro and Stiglitz (1984) actually focus on the fact that efficiency wages also lead to equilibrium unemployment. Bulow and Summers (1986) also model equilibrium efficiency wages and focus on equilibrium unemployment. They discuss how the reaction to Ford Motor Company's $\$ 5$ day for assembly line workers, introduced in 1914, is consistent with efficiency wage theory.

${ }^{9}$ See Malcomson (1999) and Gibbons and Waldman (1999) for further discussion of the empirical relevance of efficiency wage theory.

${ }^{10}$ Duflo and Hanna (2005) show that monitoring works in increasing teacher attendance in India. In their case, the employees do not have to infer the monitoring rate.
} 
One way to save on both the costs of incentives and the costs of monitoring is to rely on the intrinsic value workers get from doing their jobs well. If firms pick workers carefully and create the right work environment, won't their employees be productive? In other words, standard moral hazard models assume that all productive effort is distasteful to the employee. But perhaps this is not a reasonable assumption.

All else equal, people who are intrinsically motivated to do certain types of jobs (or, put another way, those that simply enjoy certain jobs) will go work for firms that let them do those jobs. ${ }^{11}$ If the labor market is reasonably competitive, then no matter how much workers enjoy the job, the firm will still have to pay them to do it because employers will bid wages up to the person's marginal product of labor. But, if people like their job enough, why would firms ever need to provide incentives or monitor workers?

The answer to this, and the limit to intrinsic motivation, is not that people are not intrinsically motivated or that they don't like their jobs (though this is surely true in many cases.) Rather, it's that the efficient outcome in most employment relationships is for the employee to dislike her job on the margin. Put another way, the key assumption in moral hazard models is not that all effort is distasteful. The key assumption is that the marginal disutility of effort is convex.

Many employees are intrinsically motivated to expend at least some effort at their jobs. However, at some point between zero and twenty-four hours of work in a given day, the marginal cost of an additional hour of work becomes positive. If a somewhat intrinsically motivated worker had no incentives or monitoring, she would do some work but would stop at some point. Assuming the person is still productive at the effort level where marginal work becomes costly, it is efficient to induce her to work more. It makes sense for her to work until the marginal disutility of her effort hits the marginal value to the firm.

This in no way implies that intrinsic motivation is not important. In fact, as our discussion of selection and matching below will make clear, firms should work hard to find workers who are motivated so as to decrease their own costs of compensation. But it does suggest that, on the margin, agency theory and other economic principles about motivation and incentives apply even when workers "like" their jobs.

\footnotetext{
${ }^{11}$ See Prendergast (2007) for a model of how different forms of intrinsic motivation should affect the matching of people to employers.
} 
While this very simple discussion of intrinsic motivation gets at the key economic issue regarding intrinsic motivation, it misses some potentially important and subtle effects having to do with the context of intrinsic motivation. Firms may affect employees' intrinsic rewards with the signals they send. Benabou and Tirole (2003) formalize this idea and argue that a traditional economic model can be reconciled with many of the findings by psychologists about the demotivating effects of incentives. ${ }^{12}$ They set up a model where both the employee and the firm have private information. The employee has better information about his abilities and his own interests, while the firm has better information about the attractiveness of the task. The contract offered by the firm affects the employee's beliefs about the task or the firm's beliefs regarding the employee. Under certain conditions, incentives can have negative effects on the employee.

\subsection{Responses to Incentives - Empirical Studies}

In a variety of situations where economists have been able to study the effects of incentives in relatively controlled settings, employees respond to incentives. However, while incentives "work", several studies have shown some of the unintended consequences that are created by employee incentives. That is, the "distortions" predicted by some of the theoretical work appear to be important empirically. Some of these studies, because they focus on individual firms, could be capturing mistakes. Others, which show systematic and long-term costs of incentive schemes, suggest that incentives cannot be implemented perfectly but that the costs are worth bearing.

In this section, we review the empirical work on incentives. We first review several studies that establish that employees respond to incentives. We then discuss studies that show the importance of distortions in incentive schemes. There are several important empirical papers that consider how incentives operate in group settings. We defer the discussion of these studies to Section 6, where we discuss the organization of work.

Lazear's (2000a) study of the Safelite Glass Company provides a case study of the effect of incentives on both effort and worker selection. Safelite switched from paying windshield glass installers an hourly wage to paying them a piece rate per windshield installed. Because Safelite implemented the new pay scheme at different times at different locations, Lazear (2000a) could

\footnotetext{
${ }^{12}$ For a review of many of these papers, see Deci, Koestner, and Ryan (1999).
} 
isolate the effect of the pay scheme while controlling for other company-wide changes. Also, because he was able to observe many new workers under both pay schemes and could control for on-the-job learning (that is, tenure effects), he could separate the degree to which any change in productivity was due to changes in individual worker behavior and to changes in the types of workers that Safelite was able to attract. He finds that the piece rate system increased productivity at Safelite by about $44 \%$. About half of this was the pure productivity effect. That is, the typical windshield installer that worked at Safelite under both pay schemes increased his productivity by about $22 \%$ upon the implementation of the piece rate scheme. The rest of the increase in productivity was due to the fact that the piece rate scheme led to self-selection of more productive workers into Safelite (and the self-selection of less productive employees out.)

Shearer (2004) studies how piece rates affect the productivity of tree planters in British Columbia. Working in cooperation with the company that employs the tree planters, Shearer was able to implement a true experiment where a treatment group was randomly assigned to be paid a piece rate while a control group was paid an hourly wage. This means he cannot estimate a selection effect of piece rates, but insures the validity of a causal interpretation of the incentive effect that he measures. Shearer (2004) finds that workers paid through a piece rate are approximately $20 \%$ more productive than those paid by the hour, which is nearly identical to the effect in Lazear (2000a).

Bandiera, Barankay, and Rasul (2007) consider how the implementation of an incentive pay system affects the productivity of managers of fruit pickers on a UK farm. The pickers themselves are on a piece rate system at all times, but the farm made an unannounced switch to incentive pay for managers in the middle of one season. Bandiera, Barankay, and Rasul (2007) show that the average picker's productivity increased by $21 \%$ when his manager's pay was related to his productivity. They go on to show that much of this increase is due to the managers focusing their effort more carefully on those pickers where it will have the largest marginal effect on productivity, but that at least half is due to the managers being more discriminating in which workers they select. ${ }^{13}$

Freeman and Kleiner (2005) provide a useful reminder that, while incentive pay generally increases productivity, it does not necessarily increase profits. They study a footwear

\footnotetext{
${ }^{13}$ Other studies that show evidence that incentives affect employee behavior, but where the exact "incentive effect" is not as easily interpreted, include Gaynor, Rebitzer, and Taylor (2004), Groves, Hong, McMillan, and Naughton (1994), and Fernie and Metcalf (1999).
} 
manufacturer that switched from piece rate pay to an hourly wage as part of an attempt to cut costs and change its manufacturing processes. The firm implemented numerous other changes at the time of the change in compensation system, so it is difficult to isolate the exact effect of the change in pay scheme on productivity. But Freeman and Kleiner (2005) do find a significant reduction in productivity, and an increase in profits, when piece rates were removed. ${ }^{14}$

These studies all show that incentives can be a powerful managerial tool for affecting individuals' behavior. Asch (1990) shows the same thing, but highlights the more problematic side of incentives. She studies Unites States Navy recruiters who were measured, and in some cases paid, based on their ability to enlist sailors. To the extent that productivity affected compensation for the recruiters, it was based on whether or not they met annual quotas. Therefore, recruiter incentives were low if they either had already reached their quotas or if it became apparent that they would not reach them. Also, due to discounting, the return to recruiter effort grew as the end of the measurement period approached. Asch (1990) shows that recruiting success was higher near the end of the year as the end of the measurement cycle approached. So, while incentives "worked", they did not work consistently. It is difficult to determine whether this inconsistency had any negative ramifications for the Navy.

Courty and Marschke (2004) examine the response of another set of government workers - managers of job training centers - to non-linear incentives. However, in this case the incentives are indirect in that performance affects the budget of the job training office and not the employees' compensation. Courty and Marschke (2004) show that managers act so as to increase the expected amount of incentive payouts near the end of each measurement period, but that their actions generate real costs in terms of lowering the quality of overall training. The incentives may lead to benefits in terms of overall quality, but it seems likely that these benefits could be captured without the costs imposed by the focus on year-end results.

The analyses by Asch (1990) and Courty and Marschke (2004) suggest that incentives can have a costly and inefficient side to them. However, because these studies are each based on a single institution (and one that is not subject to competition), it is feasible that they are simply studies of mistakes. Over time and facing competition, perhaps the Navy and the job training incentive systems would get changed or driven out of existence. However, there are broader

\footnotetext{
${ }^{14}$ Note, however, that this profit effect could reverse in the long-term if employees become more productive in the future due to current effort. See Friedman and Kelman (2007), who show that short-term financial incentives in British hospitals had long-run effects on productivity.
} 
(though less direct) studies of unintended consequences of incentives which suggest that firms choose to live with some of these consequences for the sake of capturing some other benefits.

Oyer (1998), for example, analyzes the effects of the fact that firms tend to plan their budgets and their incentive systems around a fiscal year. Executives and salespeople typically have contracts with a non-linear relationship between pay and performance. Salespeople often have annual quotas, for example, and many executives receive certain bonus payments only if they surpass some target. This provides these employees with incentive to try to exert some discretion over when certain results are achieved. For example, a salesperson who is rushing to meet a quota near the end of the year may offer a customer a big (but unnecessary) price break if the customer orders immediately. He shows that, controlling for the calendar seasonality of a firm's industry, firms tend to sell more (and at lower margins) near the end of fiscal years than they do in the middle of the year. They also tend to sell less early in the year, suggesting that salespeople and/or executives "borrow" from the next year to meet the current year's quota. ${ }^{15}$ Larkin (2007), using data from a large software company, finds that salespeople's reaction to their incentive contracts cost the firm $6-8 \%$ of potential revenue.

The specific example studied by Larkin (2007), as well as the broader pattern identified by Oyer (1998), raise the interesting question of why these non-linear contracts are so prevalent given that they create inconsistency in the production process and cut profit margins at the end of the year. However, given that these fiscal-year effects have been so common for so long, it appears there must be some benefit of these contracts that outweighs these apparent costs.

Chevalier and Ellison (1997) show that non-linearities also lead to persistent distortions for mutual fund managers, though these non-linearities are not chosen by firms. ${ }^{16}$ Specifically, they show that there is a non-linear relationship between mutual fund investment returns over a calendar year and investment inflows into those funds. As a result, near the end of the year, some mutual fund managers have an incentive to change the level of risk in their funds. They show that such changes in risk do occur, suggesting that mutual fund managers choose their portfolios' risk with more than just maximizing return in mind. Again, given that this distortion has been

\footnotetext{
${ }^{15}$ See Healy (1985) and Murphy (2000) for further evidence that there is a relationship between executive contracts and timing of performance within fiscal years.

${ }^{16}$ Also see Brown, Harlow, and Starks (1996), who reach similar conclusions about mutual fund managers.
} 
taking place in a competitive market for a long period, it appears that the costs imposed by this behavior of mutual fund managers are outweighed by some benefits. ${ }^{17}$

\subsection{Empirical Relevance of the Risk/Incentive Trade-off}

In a series of papers over the last decade, Canice Prendergast has explored the trade-off between risk and incentives that we discussed above. First, in a review of the incentives literature at that time (Prendergast, 1999), he argued that the empirical evidence was mixed on the risk/incentives trade-off. ${ }^{18}$ Then, in a series of papers, Prendergast (2000, 2002a, 2002b) more carefully lays out the evidence on the risk/incentive trade-off and offers several explanations for why the risk/incentive trade-off may be difficult to find in the data even if the underlying idea is correct.

In Prendergast (2002a), risky environments are likely to be those where a manager's private information is more valuable. A firm will be willing to pay the additional costs to compensate a manager for additional risk in order to make sure the manager uses his private information profitably. In other words, the marginal value of the manager's effort is increasing in environmental risk such that the natural trade-off between risk and the cost of incentives may be overwhelmed by a positive relationship between risk and the benefits of incentives. ${ }^{19}$ Initial attempts to test Prendergast's model have been generally supportive (see Adams, 2005, and DeVaro and Kurtulus, 2006), though they are limited by the difficulty of finding exogenous variation in decision rights delegation.

Prendergast (2002b) presents a model of subjective assessments and shows that either favoritism or costs to the manager of making assessments can lead firms to find incentives more valuable when risk is higher. Prendergast (2000) argues that, if the costs of monitoring effort directly are correlated with risk, then firms may use more incentives in riskier environments because the requisite risk premium is smaller than the cost of the additional resources that would be required to directly monitor the agent's actions.

\footnotetext{
${ }^{17}$ For other examples of problematic responses to incentives and measurement, see Dranove, Kessler, McClellan, and Satterthwaite (2003) and Jacob and Levitt (2003).

${ }^{18}$ See Aggarwal and Samwick (1999a) and Jin (2002) for recent evidence that the trade-off holds for American CEOs.

${ }^{19}$ Zabojnik (1996) draws similar implications in a model where a portion of market risk is related to the manager's marginal product and is revealed to the manager before she chooses her effort, though he does not model the decision rights of the manager.
} 
Oyer (2004) offers an alternative reason risk and the value of incentive contracts can be positively correlated, even when the pay scheme is not meant to affect the agent's actions. He develops a model where the employee's reservation wage and the firm's value or profits are correlated with one another because they are both affected by macroeconomic shocks. The firm ties the employee's pay to the firm's success in order to lower contracting and renegotiation costs if a shock affects the employee's outside opportunities. In environments where shocks (and, therefore, risk) are greater, the firm will tie more of pay to firm performance in order to more closely match compensation to the employee's outside opportunities. However, if the environment gets too risky, the firm will abandon performance-based compensation and renegotiate wages when conditions change. This suggests that the incidence of "incentives" will be negatively related to risk but the amount of incentive will be increasing in risk.

Prendergast (1999) summarized the research on the risk/incentive trade-off as of the time he wrote by saying, "there is some evidence that contracts are designed to optimally trade off risk against incentives" and "it would not appear that on the margin, the risk measures that have been considered are the true constraining factors on the provision of incentives." These conclusions are still appropriate. But, in the last several years, some of the extensions to the basic moral hazard model reviewed above have uncovered possible reasons the risk/incentive trade-off has been so elusive to empirical researchers. The challenge in the years ahead is to design empirical strategies and measures that can confirm or refute these newer models, as well as the basic moral hazard model.

\section{Matching Firms and Workers}

Matching firms with workers would be an easy process if labor were a commodity like some other inputs. However, labor is probably the most heterogeneous of all inputs in production functions. This is true on both sides of the market - the value of a given worker is likely to vary dramatically across potential employers and the disutility of effort associated with work will vary for a typical worker across the firms she might work for. Matching the right firms to the right workers creates economic value of a magnitude that few other economic processes can.

Given the importance of job market matching, it is not surprising that economists have been studying the selection process since well before there was a field known as personnel 
economics. Important theoretical contributions have come in two varieties - game theoretic models of asymmetric information and models of efficient matching with symmetric learning about worker productivity.

\subsection{Learning Models}

Suppose individual i's output (y) in period $t$, if employed at firm $\mathrm{j}$, can be written as $y_{i j t}=\alpha_{i}+\mu_{i j}+\varepsilon_{i j t}$

where $\alpha$ is the innate ability of worker $\mathrm{i}, \mu$ is the "match" productivity of the worker $\mathrm{i} /$ firm $\mathrm{j}$ combination, and $\varepsilon$ is a productivity shock. Suppose all three variables on the right-hand side of the equation are random variables with mean zero and variance $\sigma_{\alpha}, \sigma_{\mu}$, and $\sigma_{\varepsilon}$, respectively.

Consider the case where $\sigma_{\alpha}=\sigma_{\mu}=0$. In this case, each individual is identical and labor is a commodity. Efficiency is independent of how workers are matched to firms. If this were a reasonable representation of the world, then the field of personnel economics would not study selection of workers.

Now consider the somewhat more interesting example where $\sigma_{\mu}=0$, but $\sigma_{\alpha}>0$. In this case, workers differ in their productivity but their productivity is independent of where they work. Again, selection is uninteresting in this environment as long as information about an individual's value of $\sigma$ is symmetric between firms and the worker. ${ }^{20}$

Now consider the more interesting example where $\sigma_{\mu}>0$. In this case, which is the core of the matching model in Jovanovic (1979), a worker's expected productivity in any given period depends on where she works. In this case, it is important, in terms of economic efficiency, to maximize the firm/worker match quality $(\mu)$. Though exactly who captures the value of this match quality will differ depending on the competitive environments in the labor and production markets, the total size of the economy will increase in average match quality. In the absence of any cost of changing jobs, workers would switch jobs several times early in their careers in search of the best match. But, given some search or other transaction cost in job switching, workers will switch jobs only if the expected gains to doing so are large enough.

\footnotetext{
${ }^{20}$ While selection issues are not important in models with symmetric learning about general ability (that is, ability that is equally useful to all employers), these models have interesting implications for compensation. See Section 4.1 below.
} 
There are two key empirical implications of matching models. First, turnover rates will decrease in job tenure (that is, the longer a person stays in a job, the less likely she is to leave the job in any given period.) Second, wages will increase in job tenure. ${ }^{21}$ Both of these implications have proven consistent with empirical patterns in numerous studies. ${ }^{22}$ Unfortunately, these two implications are also consistent with models of firm-specific human capital. While the patterns in the data may appear consistent with both models, the managerial implications of these models are drastically different. If $\sigma_{\mu}$ is very high, so that match quality varies, employers should invest carefully in screening and selection. But if match quality does not vary and firm-specific human capital is an important driver of productivity, firms should focus on training and other human capital development.

Note that the matching literature is vague about what underlies the value of a match $(\mu)$. Two recent models explore this. Lazear (2004a) models a world where all skill is completely general, but employers value mixes of skills differently. Hayes, Oyer, and Schaefer (2006) emphasize the value of co-worker specific match quality. Employees are more valuable at some firms than others because they work more productively with the employees at some firms. While both these ideas can help get to the root of matching, they do not help with distinguishing matching from firm-specific human capital. The mix of skills and/or relationships with coworkers can be developed after taking a job, which would make them a form of firm-specific human capital rather than ex ante match quality. ${ }^{23}$

Two recent papers that look more directly at the importance of matching are Andersson, Freedman, Haltiwanger, Lane, and Shaw (2006) and Woodcock (2006). Andersson, et al (2006) examine the matching of the most talented software engineers to the firms with the highest returns to talent, while Woodcock (2006) analyzes the importance of individual skill, firm effects, and match-specific productivity on wages. Empirical research along these lines, which has become more feasible as rich employer-employee datasets have become available, could

\footnotetext{
${ }^{21}$ This implication will not be strictly true for a given worker over his job tenure if the match quality is immediately determined and incorporated into the wage. But if the quality of the match is learned over time, this implication will hold.

${ }^{22}$ Miller (1984) and McCall (1990) extended the basic matching model by considering job-specific and occupationspecific matching. They generate implications regarding the optimal strategy for trying jobs of different types at the beginning of careers and find supportive empirical evidence.

${ }^{23}$ Backes-Gellner and Mure (2005) test Lazear's model using German data on employer-provided training. Their results suggest that the skills mix idea is enhanced by on-the-job training, though this does not exclude the possibility that employers select employees that already have (or show the ability to acquire) the range of skills the firms need.
} 
shed some light on how the matching process takes place and how much value it creates. ${ }^{24}$ Also, research at single firms or small groups of firms that analyzes job applicants, those offered jobs who do not accept, and those who accept positions might also inform research and practice in selection and matching.

\subsection{Asymmetric Information Models}

While matching models focus on firms and workers that are equally well informed, other models consider how employees match to firms when one party is better informed. An important example of how asymmetric information can be critical in the labor market is when a person knows her ability but a firm has only a noisy estimate. If all workers were honest, firms could simply ask job applicants about their ability and make hiring decisions based on what the applicants say. Less qualified applicants have considerable incentive to exaggerate their qualifications, so firms must find another way to extract this information.

Two solutions to this problem have been suggested. In the pioneering work of Spence (1973), employers use costly signals to infer the ability of applicants. The cost to an individual of obtaining an education is inversely related to her ability (and, therefore, her productivity as an employee.) Signaling will only solve selection problems when acquiring the signal is sufficiently costly and when the cost of acquiring it is inversely related to the person's ability. Also, signaling is an inefficient solution to the selection process because the cost of acquiring the signal is a deadweight loss. Another way to separate people of differing skill is to use selfselection (see Salop and Salop, 1976). If some portion of compensation or other parts of the employment relationship differ in their value to prospective employees, and if these differences in value are related to productivity, then more productive employees will self-select into an organization. While self-selection has the advantage of not wasting the resources involved in acquiring a signal, it relies on employers being able to find a condition of employment that will separate people based on ability.

Lazear (1986a) models how incentive schemes can be useful for signaling and selfselection. Suppose that potential workers know their ability but employers do not. If productivity

\footnotetext{
${ }^{24}$ Oyer and Schaefer (2007) also use a newly available data source - directories of employees from law firms' web sites - to study the match between firms and workers.
} 
differences cannot be measured on the job, then all employees will be paid the average workers' productivity. But suppose an employer can measure an individual's productivity at some cost. Lazear (1986a) assumes that all employers in the marketplace observe the person's productivity when one employer measures it, so the firm will only undertake this measurement if the employee pays for it (presumably through lower compensation.) Once productivity is measured, employee wages are bid up to their individual productivity level. If measurement is costless, then the system fully unravels and everyone is paid exactly their productivity. But, if measurement is costly enough, then those with relatively low productivity are not willing to pay to be separated from those with the lowest productivity. As a result, some firms pay a fixed salary for all workers and attract those of relatively low ability. Other firms set up compensation systems related to output and measure workers. These firms attract workers above some ability cutoff. This model implies that, in industries and occupations where it is relatively costly to measure workers' output, workers will be more likely to be paid straight salaries. This is one reason salespeople are paid commissions, which is output-based pay, while most high level service workers are paid salaries. In the latter case, it is more costly to obtain a decent measure of output. More pooling occurs and proxies for input are used as the pay basis instead.

Now consider a different type of asymmetric information model that can lead to inefficiencies in the labor market. Suppose each employee has ability $\alpha$ as in the prior discussion and firms cannot observe an individual's ability before hiring her. However, suppose the firm gets a precise estimate of the person's ability shortly after hiring her. Then, as Greenwald (1986) shows in an extension of the early work by Akerlof (1970), under certain conditions, there can be an inefficient level of employee mobility. ${ }^{25}$ Firms use their informational advantage to retain high ability workers when they receive outside offers while not responding to outside offers made to mediocre performers (known as "lemons" in the paper.) Fearing this information disadvantage will lead them to the winner's curse and overpaid lemons, firms are reluctant to make offers. Thus, in some cases where a worker's talents would be better put to use at a new firm, this efficient movement will not take place.

In some labor markets, this may not be an issue. For example, the productivity of professional athletes (and academic economists) is readily observable to other teams

\footnotetext{
${ }^{25}$ Lazear (1986c) also formalizes the adverse selection issue in the employment setting by putting the problem in an efficient turnover and auction context.
} 
(universities) and the markets for these professionals' services are quite liquid with significant volume of trade. However, in other markets, ability is not as easily observed by outsiders and this observability need not be completely exogenous. Several models have advanced Greenwald (1986) and Akerlof (1970) by analyzing how employers can best take advantage of their inside knowledge of their workers' abilities. For example, Waldman (1984) considers strategic assignment of employees to jobs within a firm when outside firms take these assignments as signals of employees' ability. He shows that employees may not be assigned to the jobs where they would be most efficient and that pay will depend on job assignment rather than strictly on ability.

Milgrom and Oster (1987) extend this idea by considering two classes of workers - a regular group and a "disadvantaged" group. If it is easier to hide the disadvantaged group than the regular group, then firms will not promote or pay the skilled members of the disadvantaged group as much as they pay other skilled workers. This leads to persistent discrimination (that is, lower wages and under-representation in senior positions) against the disadvantaged workers and less investment in human capital by members of this group. Bernhardt (1995) also assumes that incumbent firms can exploit an informational advantage regarding employee ability and that this advantage may vary across certain classes of workers. He develops a model that is consistent with several stylized facts of some labor markets. The model also predicts the so-called "Peter Principle" where some managers are promoted to positions that are no longer appropriate for their skill levels. ${ }^{26}$

While layoffs, or even voluntary turnover, may reveal a "lemons" problem in some cases, Gibbons and Katz (1991) point out that this will not be the case when a firm fails. ${ }^{27}$ They predict that, because of the inferences drawn by employers, the reemployment wages of a worker at a plant that closes will be higher than the wages of a worker who is laid off from a continuing operation. They find some empirical evidence to support this prediction, though follow-up studies have argued that their results are fragile (see Song, 2007, and other work cited there.) Nonetheless, the insight that there might be more stigma attached to losing a job at a downsizing

\footnotetext{
${ }^{26}$ For alternative explanations of the "Peter Principle", see Lazear (2004b) where, on average, early success is at least partially good luck and Fairburn and Malcomson (2001) where risk averse managers may inefficiently promote underlings to provide them with more incentive.

27 This "stigma" of certain layoffs is similar to the signal sent by not getting outside offers in Lazear (1986c).
} 
firm than at one that is closing an operation has become widely used in the labor economics literature.

While the asymmetric information literature has been quite successful at developing realistic models that match some basic stylized facts, there has been relatively little direct empirical testing or estimation of these models. ${ }^{28}$ There are several reasons for this and, while empirical work would certainly be informative, it will likely continue to be difficult. Probably the biggest challenge to empirical researchers is the lack of measures or proxies for some of the key parameters in these models. For example, it is hard to find a convincing measure of the degree to which an employee's ability is observable to other employers or a proxy for the costs of measuring an individual's output.

\subsection{Firing and Displacement}

In addition to selecting workers when they hire them, firms have the opportunity to change their selection of workers at any time by layoffs. If firms could freely adjust wages to an employee's marginal product, then worker displacement would not be an issue because workers would make efficient voluntary decisions about when to leave. However, due to wage compression within firms, norms against nominal wage reductions, and other factors, workers often do not voluntarily quit when firms would like them to.

Most worker displacement is simply the result of some significant negative shock to a firm or its industry or is the result of an individual proving to be significantly less productive than the firm anticipated. This type of turnover does not generate particularly interesting insights into how firms manage their human resource systems, so we do not cover it in detail here. It is worth noting, however, that displacement typically has negative and economically significant consequences for workers due to loss of firm-specific human capital (or match-specific productivity), stigma of losing a job, or other factors. See Farber (2005a) and Kletzer (1998) for reviews of the frequency and effects of job loss in the United States and Hallock (2006) for a discussion of the layoff process.

One way that displacement affects the way firms run their personnel systems is through limits that are placed on firm's ability to dismiss workers. A firm making decisions about who to

\footnotetext{
${ }^{28}$ See DeVaro and Waldman (2006) for one recent empirical study on this issue, focusing on a single large firm.
} 
hire and whether to hire may act differently if it loses the option of correcting bad hiring decisions through dismissal. Consider a firm weighing the possibility of taking on a particular candidate. The firm trades off the expected costs and benefits of hiring that person versus its next best option (which may be an alternative candidate or it may be to not hire at all.) The firm will typically have an imperfect estimate of the benefits an employee will bring the firm because it does not know the person's ability (or match) exactly and the firm's business environment could change in a way that affects the potential employee's marginal product.

Consider a firm that is choosing between candidate A and candidate B. Normalize the person's expected marginal product of labor in a given period to (and, therefore, their reservation wage) to 0 . But suppose that candidate A produces 0 for sure, candidate B produces either $z$ or $-z$ (each with $50 \%$ probability), and output-contingent contracts are not feasible. Assuming everyone is risk neutral and the person is hired for only one period, a firm would be indifferent between the two candidates. However, if the employment match can last multiple periods, then, under certain conditions and all else equal, the firm will prefer type-B workers for their option value. In equilibrium, type-B workers will earn a wage premium and only certain types of firms will want these workers. Lazear (1998) develops a model along these lines, where he explores the market equilibrium when workers have option value. ${ }^{29}$ The option value of risky workers will be highest in contexts where workers are somehow tied to their firms and where it is relatively easy for employers to dispose of workers that turn out to be unproductive.

In many cases, firms face barriers to dismissing workers due to legal or other institutional (for example, union) reasons. This makes the cost of employing workers higher, lowering labor demand, and can lead to some combination of lower wages and lower employment. ${ }^{30}$ In addition to lowering overall labor demand, firing costs can reverse the logic of preferring risky workers for their option value because substantial negative realizations relative to expected productivity can be very costly. That is, a firm that cannot lower wages substantially will want to fire a type-B worker that turns out to have productivity of $-z$. If firing costs are substantial enough, then the costs of hiring an unproductive type-B worker can outweigh the option value of having a

\footnotetext{
${ }^{29}$ See Bollinger and Hotchkiss (2003) for an analysis of risky hires in professional baseball. Lazear (1998) may also apply to academic labor markets because moving costs tie professors to their institutions while the tenure system allows schools to displace workers relatively easily.

${ }^{30}$ As Lazear (1990) points out, perfectly efficient labor markets could undo the negative consequences of firing costs. However, as Lazear (1990), Deterzous and Karoly (1992), DeLeire (2000), Acemoglou and Angrist (2001), and Autor, Donohue, and Schwab (2006) show, there is substantial evidence that firing costs increase unemployment.
} 
productive type-B worker. Oyer and Schaefer (2002) model how equilibrium wages and employment will change for different types of workers when these workers differ in the observability of their ability or productivity. They argue that increases in firing costs that are constant across workers should increase the wage premium to seniority because employers have more precise estimates of the ability of workers with more experience. They find support for this model empirically, using labor market and civil rights litigation data around the time of an increase in employer liability for discrimination in displacement.

In addition to affecting the "riskiness" of workers a firm would want to hire, firing costs will also affect the types of workers that a firm will displace. If the costs of firing a worker increase, a firm will be willing to live with a worse worker because the benefits of firing the previously marginal worker will no longer outweigh the costs. This implies that those workers that a firm fires when firing costs are high will be, on average, of lower ability than the ones it fires when firing costs are low. Empirical support for this idea has been found using variation in

firing costs generated by three different institutional settings - American Civil Rights legislation, institutional barriers to worker displacement in Europe, and firing restrictions imposed by state courts and legislatures. Oyer and Schaefer (2000) find evidence consistent with this by using variation in firing costs by race. Extending this logic one step, the "stigma" that Gibbons and Katz (1991) argue will go along with displacement should be greater when firing costs are greater. Canziani and Petrongolo (2001) formalize this idea and find empirical support using data from Spain around the time of easing of firing restrictions in the mid-1980's. Kugler and SaintPaul (2004) develop a similar model, focusing on the choice of firms to hire workers that are unemployed or working at other firms. Using variation in firing restrictions across American states, they find that the "lemons" effect increases in firing costs.

\section{Compensation}

\subsection{The Level of Compensation}

How much will firms pay their employees? In the absence of incentive issues and any firm-specific productivity, compensation will be just enough to keep employees from leaving the firm (as long as the firm does not lose money). In equilibrium, this will be equal to the expected 
marginal product of the employee's labor. But how do firms and employees determine an employee's marginal product? How do they know what is a reasonable amount to pay? For some employees with a lot of experience, firms and workers have a pretty good idea of what a reasonable wage is. But, when an employee enters the labor market, firms have to rely on observable features such as the person's education, performance in interviews, and performance on tests. Over time, firms and employees learn more about the employees' skill and tailor jobs and his pay accordingly. ${ }^{31}$

Farber and Gibbons (1996) model this learning process. Consider a person entering the labor market. The firm that hires him expects his productivity $\left(y_{i t}\right)$ to be $y_{i t}=F\left(\alpha_{i}, X_{i t}\right)$

where $\alpha_{i}$ is the innate ability of worker $i$ and $X$ is a set of characteristics that are observable to the firm (such as education). Because neither the firm nor the individual know the exact value of $\alpha$, initial wages are based largely on $X$. However, over time, the firm observes a set of noisy signals about $y_{i t}$ and updates its estimate of $\alpha$. Farber and Gibbons (1996) derive empirical implications of employer learning on the measured correlation between pay and $X$, as well as how pay is related to characteristics firms cannot observe at the time of hiring. Using data from the National Longitudinal Survey of Youth, they find empirical results that are broadly consistent with employer learning playing a large role in the development of wages over careers. ${ }^{32}$ Altonji and Pierret (2001) develop this idea further and point out that, until the learning process is fairly developed, employers are statistically discriminating on the basis of the observable $X$ characteristics. A key point in these models is that the level of pay will more closely approximate the worker's marginal product as the firm and worker learn about the worker's true ability.

Competitive labor markets do not require that workers earn their expected marginal product in any given period. Firms may set implicit contracts across multiple periods as a means of facilitating long-term relationships, providing incentives, or more efficiently sharing risk. Lazear (1979) focuses on the long-term relationship and incentives ideas. He notes that a firm can provide incentives through fixed wages if the firm pays the worker less than his marginal product early in his career and more than his marginal product later. After a person has been at

\footnotetext{
${ }^{31}$ See Waldman (2007) for a more detailed survey of careers in organizations.

${ }^{32}$ Gibbons, Katz, Lemieux, and Parent (2005) and Lluis (2005) extend this learning model and the empirical analysis in Farber and Gibbons (1996) by noting that employees may have differing productivity in different sectors. Firms and workers learn about workers' innate skill, as well as which sector best fits their skills, over time.
} 
the firm for a while, he has incentives to perform well and avoid being fired in order to enjoy the rents he has been promised later. Because this ties the worker to the firm, it may also encourage development of firm-specific human capital. Older workers are "overpaid" in this model and need to be induced to leave the firm either through a mandatory retirement policy or an appropriate pension scheme.

Harris and Holmstrom (1982) model wage dynamics over careers when employees are risk averse and when firms and workers learn symmetrically about workers' ability. In their model, workers are insured against negative shocks to their realizations on ability. In equilibrium, individuals never have wage decreases and wages increase faster than productivity. Frank (1984) offers an alternative explanation for why workers may not be paid their marginal product and why wages are generally thought to be more compressed than productivity. He argues that, if workers care about their pay relative to their peers within the firm, high ability workers will be willing to take a wage discount for the value they get from being near the top of the pay scale.

A look inside firms shows that actual wage dynamics are driven largely by the jobs people hold. That is, individual jobs have a fairly narrow band of possible wages. The learning process that leads to people settling into the appropriate compensation scheme over time appears to be largely about finding the right job for the person, rather than finding the right pay for different people doing similar jobs. This can be seen in the firms studied by Lazear (1992), Baker, Gibbs, and Holmstrom (1994), and several more recent studies (see Waldman, 2007, for more details.)

\subsection{The Mix of Compensation}

Money isn't everything, but everything can be expressed in terms of its monetary equivalent. That is, in most markets, consumers pay some amount of cash in return for a good or a service. In some labor markets, such as temporary help or "under-the-table" work, transactions take this form. But most people sell labor services in exchange for a range of cash and other compensation. Interpreted broadly, the "other compensation" can include standard non-cash benefits such as health care, retirement benefits, and employer-sponsored child care as well as "amenities" such as a large or nicely decorated office, low risk of injury or death, or a job that 
consists of largely interesting tasks. If all firms had the same cost structure, all employees had the same preferences, and employees could buy any amenities or benefits from other sources for the same prices the employer would pay to procure them, then labor would be traded for money and individuals would buy their own basket of benefits to best suit their needs.

However, either due to institutional features such as tax incentives or simply due to economies of scale, firms often have a comparative advantage in providing benefits or amenities relative to workers. In addition, some firms are better at providing benefits than other firms and individuals vary in terms of how they value benefits. For example, a restaurant can more costeffectively provide meals to its employees than a firm that manufactures ball bearings and some people place a higher value on food provided by their employer than other people. ${ }^{33}$

These forms of differentiation lead to two important conclusions. First, it is often efficient for firms to provide a compensation package that mixes cash with other things. ${ }^{34}$ Second, the total economic value of employment relationships can be enhanced by matching workers who value a given benefit or amenity with firms that have a comparative advantage in providing that benefit. That is, one of the determinants of the match-specific surplus discussed in Section 3.1 is the degree to which a firm efficiently provides amenities valued by its employees.

The classic work by Rosen (1974) laid out the theoretical foundations for this job differentiation and Rosen (1986) provides an intuitive discussion of how this model leads to the theory of compensating differentials in labor markets. Rosen (1974) shows how market equilibrium prices allow inferences about the monetary value of some characteristic. For example, suppose that we want to determine the monetary equivalent value of interesting work in a firm. Define $\mathrm{X}$ as the proportion of tasks on a given job that are new to the employee. Suppose that data were available on wages and the proportion of tasks on a job that were new per day. Consider the following regression:

Wage on job $\mathrm{j}=\mathrm{a}+\mathrm{b}$ (Proportion of new tasks per day on job $\mathrm{j}$ )

\footnotetext{
${ }^{33}$ For alternative justifications of certain benefits, see Rajan and Wulf (2006), Marino and Zabojnik (2007), and Oyer (2008). They consider the relationship between benefits, employees' cost of effort, and productivity.

${ }^{34}$ Employer-provided health care and pensions account for a large share of the cost of employee benefits, as well as of economics research on benefits. Gruber (2000) reviews the huge literature on employer health insurance. The large literature on pensions focuses on the various types of pensions offered and how they affect retirement behavior. See surveys by Lumsdaine and Mitchell (1999) and Lazear (1986b).
} 
The coefficient $b$ reveals the value that the market places on having flexibility on the job. The coefficient reflects the market value and not necessarily the tastes of any one individual. Employees that value new tasks relatively highly can earn rents by taking jobs at firms that offer many new tasks and firms that can provide new tasks to workers at relatively low cost can earn rents by providing a relatively high proportion of new tasks. Rosen $(1974,1986)$ discusses the conditions under which the market "price" reflects individual tastes, firm technologies, or neither.

There is an empirical literature that attempts to examine the relation of wages to nonmonetary benefits and to determine the "price" of various benefits and amenities. ${ }^{35}$ These analyses are very challenging, however, due to the effects of unobserved ability. Consider two people who are observationally equivalent (same age, education, etc.), but one has more skill that is observable to employers and unobservable to an econometrician. The higher skill employee will be able to command higher total compensation. However, due to regressive taxes on cash compensation and the fact that income effects will generally make the marginal utility of workplace amenities (relative to cash compensation) higher for higher paid workers, higher ability workers will take some of their additional compensation in the form of workplace amenities. As a result, Ehrenberg (1980) found that pensions and wages were positively correlated (when there should be a tradeoff between the two) and numerous studies have shown that wages are positively related to benefits. ${ }^{36}$ This does not mean that hedonic wage theory or the concept of compensating wage differentials is wrong. It just means that measuring the market price of these differentials is difficult.

There are at least three potential ways that future research can get around the challenges presented by unobserved ability. First, if there are variables that are correlated with whether a person gets a benefit at work but not otherwise related to that person's earning potential, then instrumental variables can be used to identify the salary/benefit trade-off. Olson (2002) uses this approach to estimate that married women will accept a $20 \%$ salary reduction in return for health insurance, using their husbands' union status and firm size as an instrument for whether the women have employer-provided health insurance. While this approach can be useful when

\footnotetext{
${ }^{35}$ See Antos and Rosen (1975), Thaler and Rosen (1976), Brown (1980), and Woodbury (1983) for early examples of this literature.

${ }^{36}$ Hamermesh (1999) and Pierce (2002) highlight an interesting implication of the income effects of benefits. They show that changes in wage inequality in the U.S. in recent decades understate the total increase in compensation inequality as benefits have become relatively more generous for high-paid workers.
} 
looking at health insurance, the value of other benefits is unlikely to be high enough to allow for precise estimation of the salary/benefit trade-off. Second, detailed information on multiple job offers to the same person can provide estimates of trade-offs, assuming the value of the employee is roughly equal to the various employers. Stern (2004) takes this approach by surveying scientists about the compensation and research components of their job offers. His estimates suggest scientists are willing to accept substantial wage decreases to engage in on-thejob research. However, highlighting a potential weakness of this approach, his estimates are imprecise because his sample size is small and respondents' recall of job offer details is likely to include substantial measurement error. Finally, given that benefits are such an important part of human resource policies, a large firm might be willing to work with economists to design experiments that randomize across workers by location. Large firms that have many locations and are known for providing generous benefits (such as Starbucks or Whole Foods Markets) are promising candidates. Laboratory experiments may also be helpful for learning about how people view benefits relative to cash, but the short-term and relatively low stakes nature of that environment is likely to be an important limitation.

\subsection{Equity Ownership}

Over the last few decades, stock and stock options have grown as compensation tools. This probably reflects several factors, including attempts to increase worker incentives and the fact that, as economic growth has made workers wealthier, employee risk aversion may have gotten lower. Think about a middle manager at a large firm. If this person were truly risk neutral, he would be indifferent between taking his compensation in the form of cash or in terms of company stock. The stock would have the benefit of aligning his incentives with those of other shareholders. However, given that this manager's efforts have only a trivial value on stock holdings, it would be difficult to generate incentives unless the firm issued him huge amounts of stock (as in Holmstrom, 1982.) In this case, risk costs would certainly become important. So why do firms grant stock to employees?

One possible answer is to retain employees, as in the Oyer (2004) model we discuss elsewhere. Another possible answer is to attract the right employees. There may be several "sorting" benefits of making equity compensation part of the employment agreement, even in the 
absence of incentives. The manager who has many stock options and a low base salary does not earn much unless the company does well. Thus, a manager who is willing to take a job under these circumstances reveals that he believes in the company. This information may be valuable to investors, whose information about the true value of the company is not as good as that of managers. See Salop and Salop (1976) and Lazear (2005).

Similarly, equity compensation, like any other non-cash benefits, may be used when a firm can provide it at relatively low expense and the employees value it. That is, firms can use equity-based pay to lower compensation costs by attracting employees that are particularly optimistic about the firm's prospects. A slightly different, but closely related, idea is that, if workers that are optimistic about a firm are also the most productive (perhaps because of enthusiasm or an understanding of the firm's environment), then equity-based pay would just lead to the type of self-selection in Salop and Salop (1976) that we discussed above. See Oyer and Schaefer (2005) and Bergman and Jenter (2007) for theoretical and empirical analyses of this idea in the context of broad-based stock option plans.

While attraction and retention may be important reasons to grant equity to employees, perhaps the most important justification for equity-based pay is to generate incentives. This explanation is likely to apply in small firms or among very high-level managers at large firms. These employees can have an important impact on the firm's value and the incentive effects of ownership can outweigh the inefficiency in asking these employees to bear the risk of factors beyond their control that affect firm value.

\subsection{Executive Compensation}

One set of workers that has been widely studied, with much of this work falling in the arena of Personnel Economists, is top executives. There are several reasons why executives have received more than their share of attention in the personnel economics literature. ${ }^{37}$ First, executives (and especially Chief Executive Officers, or CEOs) receive a great deal of compensation. The average CEO of a large American company now makes several million dollars per year and the growth rate over the last few decades has been much faster than for compensation more generally. Second, due to disclosure regulations, publicly traded firms have

\footnotetext{
${ }^{37}$ This is certainly true on a per-worker basis and is probably still true on a per-compensation-dollar basis.
} 
to provide information about both executive compensation and company performance. This allows empirical economists to create large datasets of individuals" pay and "performance" (where performance is a firm's stock return or measures based on a firm's or division's accounting statements.) For these reasons, CEOs and other executives have been widely studied.

Murphy (1999) documents the rise in executive-related academic work, as well as providing a summary of this literature. We refer readers interested in details on the institutional features, the level and structure, and the politics of executive pay to Murphy's review.

We will, however, highlight a few stylized facts from the executive compensation literature that relate directly to personnel economics. First of all, as one might expect given the large effect CEOs can have on firms' outcomes and the relatively easy availability of performance measures, CEOs have high levels of incentive-based pay. Much of this is based on explicit incentives such as performance-contingent bonuses and equity ownership. A smaller, but important, amount of incentives comes in the form of subjective or implicit incentives including adjustments to salary and bonuses not tied to objective metrics. These incentives vary in ways that most theories predict, with stronger incentives at firms where the marginal product of the CEO is likely to be higher (such as larger firms, firms with more capital, and unregulated firms.)

Murphy (1999) also shows that executive turnover is somewhat based on firm performance, but that the relationship is not as strong as one might expect and, at least as of the time of his writing, had weakened over time. He also shows that there is a surprising lack of relative performance evaluation (RPE) in executive pay. Executives are rewarded (penalized) for good (bad) macroeconomic conditions, though it would seem easy for firms to filter this uncontrollable risk out of pay/performance contracts.

Murphy's (1999) survey ends with suggestions for future research. He asked why RPE is scarce $?^{38}$ Numerous explanations have been suggested since Murphy posed the question. First, in trying to justify the lack of RPE for executives, Garvey and Milbourn $(2003,2006)$ have provided both "supply" (that is, executive-driven) and "demand" (firm-driven) explanations. They argue that there is RPE for some executives, but that the average effect is small because there are many cases where RPE is not used. In Garvey and Milbourn (2003), they argue that

\footnotetext{
${ }^{38}$ See Bertrand and Mullainathan (2001) for details on the lack of RPE in executive compensation. Note that Murphy (1999) also posed the question of why has executive pay increased so much in recent decades. Several explanations have been put forward. However, because these explanations are largely a debate about corporate governance rather than personnel policies, we do not address that issue here.
} 
RPE is unnecessary once an executive attains sufficient wealth. Once his assets that are not part of current compensation are large enough, he can completely undo any position in the firm's stock in his private portfolio such that the use of RPE is irrelevant. Consistent with this idea, they find that younger and less wealthy CEOs, who are less likely to have sufficient assets to unwind compensation contracts imposed by the firm, have higher levels of RPE. In Garvey and Milbourn (2006), they suggest that CEOs will try to influence boards of directors to limit RPE when the market is performing well. They then show empirically that CEOs are more likely to have their pay indexed during bad times than during favorable markets.

Aggarwal and Samwick (1999b), influenced by an idea proposed in Fershtman and Judd (1987), suggest that RPE will be counter-productive when products are strategic substitutes (as in differentiated Bertrand markets) and when market competition is imperfect. Pay based on relative output will lead managers to be too aggressive in product market competition. They find support for this empirically by showing that the typical level of RPE is higher when product market competition is more intense.

Oyer (2004) models a case where agents' reservation wages are driven by systematic (that is, market-wide) shocks. In order to reduce contracting and turnover costs, firms use equity ownership knowing that compensation will fluctuate with market conditions. Options or shares in the firm's stock can therefore serve two purposes. While providing shares for incentive purposes would be most efficiently done with RPE, the secondary purpose of efficient contracting when reservation wages vary is most efficiently done with pay that is indexed to the market.

Yet another possible explanation for the lack of RPE is that the marginal return to effort may be correlated with the state of the market. Suppose the firm's value ( $\Pi$ ) is an additively separable function of the CEO's effort (e), macroeconomic conditions $(\theta)$, and an idiosyncratic shock $(\varepsilon)$, so we can write $\Pi=\mathrm{v}_{1} \mathrm{e}+\mathrm{v}_{2} \theta+\varepsilon$. Then it is clearly optimal to filter out the macroeconomic effects. But if the marginal product of effort $\left(\mathrm{v}_{1}\right)$ is correlated with the macroeconomic shock $(\theta)$, then the optimal contract will be an increasing function of $\theta$.

Just as we might expect CEO pay to use RPE, we might also expect relative outcomes to affect CEO dismissals. Barro and Barro (1990) who focused on bank CEOs, found that pay is not related to relative outcomes but turnover is. Two more recent and broader studies, however, show that CEO turnover is affected by both overall market conditions and relative performance 
of individual firms. Jenter and Kanaan (2006) and Kaplan and Minton (2006) both show that CEO turnover is higher when the firm's industry performs poorly and when the firm underperforms the industry.

\section{Skill Development}

The analysis and discussion to this point has been naïve in that it took the person's ability and match-specific productivity as given. In reality, people develop skill over time both before and after joining a given firm and this skill development affects productivity. As Becker (1964) laid out in his classic study of human capital, people can develop general skill that is equally useful to multiple employers (and, therefore, becomes part of what we called ability, or $\alpha$, in Section 3.1) or that is more useful to one employer than to any other (and, therefore, becomes part of the match-specific component, or $\mu$, in Section 3.1.) $)^{39}$

Becker (1964) argued that the efficient way to divide the investment costs of skill is for firms to pay for firm-specific human capital acquisition of workers and for workers to pay for their own general human capital. Any other means of splitting human capital investments costs will lead to the potential for the firm or the worker to "hold up" the other party after sinking the cost of a relationship-specific investment.

This allocation of human capital investment clearly applies in most situations and, in particular, when the investment is large. For example, almost all people pay the cost of their own secondary, college, and graduate education. There are exceptions such as firms that sponsor their employees getting MBAs, but these arrangements often come with a contractual commitment not to leave the firm for some set period. Similarly, firms generally pay employees the going wage during training periods and early in job tenure while the employee is largely acquiring the skill and knowledge necessary to be productive in a given firm. ${ }^{40}$

\footnotetext{
${ }^{39}$ One important idea related to human capital is the extent to which incentives to acquire general and firm-specific human capital are related to promotions, careers within organizations, and even optimal organizational form. See Kahn and Huberman (1988) on up-or-out contracts, Prendergast (1993) on the relationship between promotion and firm-specific human capital, and Levin and Tadelis (2005) on partnerships in high-skill industries.

${ }^{40}$ Note that it is often difficult to determine whether a firm or a worker have paid for the acquisition of skill because we do not generally have complete information on both the compensation arrangements in a given job and what those arrangements would be in the absence of skill acquisition.
} 
Recently, a number of papers have argued that Becker's optimal allocation of human capital investments does not appear to be applied in certain situations and tried to explain why. There are situations that are fairly clear examples of firms paying for the acquisition of workers' general human capital. For example, Stanford University offers free computer training in a variety of programs to all employees, sometimes including programs not related to a person's current job. Employees who take advantage of this suffer no compensation ramifications and are allowed to attend the training while being paid. A series of recent papers have attempted to explain why situations may arise where firms find it in their best interest to pay for employees' acquisition of general human capital. Most of these papers focus on the same informational advantage of incumbent firms modeled by Greenwald (1986) and discussed in the prior section.

An example is Autor (2001), who focuses on a specific example that clearly violates Becker's model. Manpower Associates is a large U.S.-based temporary help services firm. This firm offers potential "temps" free computer training. The training provides skill in common computer programs, is completely free to the person, and is not coupled with any obligation to work for Manpower. A person can take this class and then go down the street to another temp agency or any other employer and use her new computer skills.

Why would Manpower offer such a program? Autor (2001) argues that the process of training gives the firm asymmetric information about the ability of the temporary worker. The firm then can use that information to match temps to assignments in a way that creates rents, at least until the person has been out on enough assignments that another temporary agency can infer her ability and where to assign her. He argues that this information advantage may be made even more valuable when free training helps a temporary help agency attract higher quality workers. He develops a model of the agency's acquisition and exploitation of private information, arguing that it will lead to particular relationships between market wages, training, and the degree of local temporary labor market competition. He then uses data from a Bureau of Labor Statistics survey of Temporary Service suppliers and finds evidence that is consistent with the model's predictions. For example, firms that offer free training offer slightly lower wages, but this gap gets smaller in more competitive markets.

Acemoglu and Pischke (1998) offer a related explanation for firms making investments in general human capital, based on the information structure in Greenwald (1986). In their model, firms have some level of monopsony power over workers and can capture some of the rents 
associated with acquisition of general human capital. Because workers do not capture the full value of general human capital investments, they will underinvest in these skills. Some firms may therefore find it profitable to sponsor this training. They find evidence consistent with the predictions of their model using a test, in the spirit of Gibbons and Katz (1991), that looks at the relative wages of German apprentices that stay at the firm that trains them, those that quit and move to another firm, and those that quit for an exogenous reason (random selection into the military.)

In another study, Acemoglu and Pischke (1999) show that, even in the absence of information asymmetry, firms may sponsor general training if wages in the labor market are compressed relative to workers' marginal products. This compression, which they argue can arise from search costs or other transaction costs or from institutional factors such as unions and minimum wages, may differ across labor market settings leading firms in some markets to be relatively likely to sponsor human capital investments.

Another justification for firms making investments in worker general human capital is that it may provide incentives for the employee to stay at the firm while in training. Flaherty (2006) analyzes data from a single non-profit institution's training programs and from a crosssection of firms. She finds that training is related to increased employee retention.

The work by Autor, by Acemoglu and Pischke and, to a lesser extent, by Flaherty focuses on general training of relatively low-skilled workers. There are interesting examples of firmprovided general human capital for higher skilled workers, often including cases where the training is highly visible to outside employers. For example, both of us (the authors) previously held positions at business schools that offered part-time MBA programs for people with full-time jobs. Most of these students were sponsored by their employers and were not paid less than people doing similar jobs (though some firms required workers to partially repay these investments if they leave before a specified time.) Future research focused on advanced training and degree programs might provide useful insights into optimal human capital investment for high-skill workers.

\section{Organization of Work}


To this point, we have acted as though a firm picks a single worker to do a well-defined set of tasks. However, in reality, firms are made up of a group of diverse people doing different sets of tasks. In this section, we briefly look at how firms decide who does what, who works with whom, and who works for whom.

\subsection{Job Design}

Most firms beyond some minimum size set up organization charts that show individual jobs designed to do some set of tasks. Several studies of individual companies, including Lazear (1992), Baker, Gibbs, and Holmstrom (1994), and Gibbs and Hendricks (2004), show how firms divide jobs into well-defined pay grades. Given this importance of jobs, how do firms divide tasks into jobs?

Rosen (1978) develops a model of firms and workers matching based on the tasks firms need done and the comparative advantage of workers in performing each of these tasks. (See Sattinger, 1993, for a review of assignment models.) In many ways, this model matches firms to workers based on tasks the same way that Rosen (1986) models firms and workers matching based on employee preferences. A similar model underlies the analysis in Gibbons, Katz, Lemieux, and Parent (2005), which highlights the importance of assigning workers to their most productive sector. Gibbons and Waldman (2006), on the other hand, develop a model where workers develop task-specific human capital so that a person's job assignment has important effects on how her career develops. ${ }^{41}$

\subsection{Teams, Worker Interaction, and Human Resource Practices}

Successful human resource management is not simply a matter of giving each individual proper incentive to engage in work in isolation. If it were, there would be no need for the firm. Perhaps the greatest value of the firm is that it provides a mechanism for people to work together and take advantage of complementarities in their skills and interests. The evidence that there can be gains from assembling workers into teams or groups has to be done at a firm-by-firm level

\footnotetext{
${ }^{41}$ For other models of how tasks get divided into jobs, see Cremer (1986) on how career concerns affect job design, Garicano and Rossi-Hansberg (2006) on dividing tasks based on skill level, and models discussed in Section 6.3 below on the division of tasks between managers and other employees.
} 
because of the need for data on productivity and team structure. As a result, much of this work falls into the category of "insider econometrics." Ichniowski and Shaw (2007) review this method elsewhere in this volume. We will briefly discuss a few papers related to the issue of group incentives.

Hamilton, Nickerson, and Owan (2003) study a garment manufacturer that switched from an individual piece rate system to group-based piece rates. Workers were given some discretion over when they made the switch. Though the most productive workers had the most to lose financially from the switch, they tended to be early adopters. Productivity went up (and stayed higher) overall, suggesting that collaboration was valuable at this company. The gains were greater for more heterogeneous teams and more able team members had a bigger influence on others' productivity than less able team members. Not all manufacturers get such positive results from the switch to teams, however. King (1998) provides anecdotal evidence of a much different (and much less successful) transition to teams at Levi's.

Boning, Ichniowski, and Shaw (2001) look at the effects of team production in the steel industry. Most firms in their sample pay some sort of group-based incentive, but only some organize their workers into cooperative teams. They find that productivity is higher at firms that use teams and that this effect is especially large where the product and production process are more complicated. Incentive pay is also associated with higher productivity at these firms. ${ }^{42}$

What are the sources of these group-based productivity benefits? In some cases, groups allow people to solve problems better and to take advantage of different skills. Gant, Ichniowski, and Shaw $(2002,2003)$, again focusing on the steel industry, show that interactions among a larger set of workers are associated with higher levels of production.

Mas and Moretti (2006) show how supermarket clerks are affected by the productivity of other clerks working at the same time. They find that high-productivity clerks increase the productivity of peers. Like Hamilton, Nickerson, and Owan (2003), they find larger productivity gains when groups of workers are more diverse in skill. Mas and Moretti (2006) also find evidence suggesting social pressure is important, because productive checkers have larger effects

\footnotetext{
${ }^{42}$ Incentives are group-based in these steel mills. However, individual incentive pay can be used to undo some of the potentially problematic aspects of production in groups of people that may try to capture some of the rents of production (either from other workers or from the firms.) Bandeira, Barankay, and Rasul (2006) show that managers on a fruit picking farm allocate workers more efficiently when the managers are given incentive pay. Some of this productivity improvement comes at the expense of the managers' friends, who receive worse assignments under the incentive pay plan.
} 
on peers that can see them while they work. Similarly, Ichino and Maggi (2000) show that absenteeism and misconduct has an effect on peers in an Italian bank.

In addition to these field studies, Falk and Ichino (2006) find noteworthy peer effects in an experimental environment. Subjects were given a mundane task (stuffing envelopes) and no financial incentive. Average worker productivity was higher when each person worked in the same room as another person than when people worked in isolation. The least productive workers were the most affected by working in a group, so the increase in their output more than made up for the decrease in output of the most productive workers. The results of all these studies taken together suggest that, at least in many environments, people prefer working in groups to working in isolation, people working in groups feel some pressure to keep up with the efforts of those around them, and/or the most productive workers pressure others into working harder.

As the theoretical work of Milgrom and Roberts (1990) and Kandel and Lazear (1992) suggests, the effectiveness of team-based systems is likely to vary from firm-to-firm due to complementarities across human resources practices. That is, team-based productivity may be more important when firms invest in selecting employees carefully, training people in the system and other practices. Testing this idea empirically is challenging, however, because measuring productivity is difficult and human resource practices are adopted endogenously. Several studies (see, for example, Black and Lynch, 2001, Cappelli and Neumark, 2001, and Bloom and Van Reenan, 2007) have shown that adoption of progressive workplace practices are correlated with one another and with productivity. However, it is difficult to make any causal statements about these relationships.

Ichniowski, Shaw, and Prennushi (1997) allay this concern to some degree by looking at productivity of individual steel production lines around the time of adoption of modern human resource practices. They show that these practices increase productivity in these factories and that the marginal effect of each practice is increasing in the adoption of other practices.

\subsection{Hierarchies}

Most people work in a hierarchy with several levels of reporting responsibility. There are many contributing factors to this standard institutional arrangement and we will not investigate 
this in any great detail because it is the focus of another chapter in this volume (see Garicano and Van Zandt, 2006.)

As we noted in some detail above, one benefit of hierarchies is that they provide incentives. Hierarchies can also be a substitute for incentives, however, in that they can provide a mechanism for monitoring employees directly. Lucas (1978), formalizing ideas in Manne (1965) and elsewhere, develops a model where some people are simply endowed with superior management skills. These skills can be interpreted as monitoring, decision making, motivating, or any other skill that would be more valuable for a manager than for other employees.

Rosen (1982) distinguishes between the managerial tasks of making choices about what to produce, strategy, etc. ("management") and insuring that employees carry out these decisions ("supervision"). To best utilize superior management skills, it would be efficient to grow firms ever larger. However, there are diseconomies of scale in supervision, so optimal firm size trades off these two factors. Rosen's (1982) model can explain skewed firm size within an industry and skewed compensation within a firm.

Garicano (2000) models hierarchies as a means of matching problems to those in an organization that can most efficiently solve them. There would be no need to use a hierarchical structure for this issue if everyone knew who was capable of solving which problems. But, when there are costs of communicating this knowledge, expertise organized by levels efficiently gets the right person to the right problem. Hierarchies are arranged with the highest skill person at the top, the next highest skilled people at the next level, and so on to the lowest skill workers at the bottom. Each new problem enters the firm at the lowest level and gets bumped up the hierarchy until it reaches the person that can solve it. Given the increasing importance of services and "knowledge workers", this idea of knowledge-based hierarchies has become more important. See Garicano and Van Zandt (2006) for discussion of recent related work.

\section{Conclusion}

We have described a great deal of progress in the personnel economics literature. This research has helped explain how firms operate and has helped shape business education curricula in recent years. So it seems sensible to ask "where do we go from here?" There is plenty of room for more work, especially empirical work, in all the areas that we have discussed. But it seems 
likely that the highest returns will come from careful analyses of the selection, sorting, and matching processes. How do firms find the right workers? How important is it that firms find the right workers for their particular context? Business school curricula and the business press are filled with many case studies of firms that highlight finding people that match their specific needs (Southwest Airlines, SAS Institute, and Whole Foods Market are prominent examples). How do these and other companies generate economic value by finding the right people?

Another question worth further pursuit is how employees value different fringe benefits. As employees become wealthier and as technology breaks down the work/leisure divide, firms are likely to find non-cash compensation more strategically useful. Some of the types of on-thejob skill development we discussed can also be thought of as non-cash benefits. Why do firms train employees in computer skills and send them to executive education training? Is it to increase their productivity, to reward them, or to signal something to or about them?

In addition to these broad areas, we have also noted some specific questions presented by recent work that are worth pursuing. What explains the lack of evidence to support the risk/incentive trade-off predicted by moral hazard models? Are American executives overpaid? How would we ever know? Other questions will emerge as external and institutional features evolve. For example, if the returns to skill continue to increase, how will firms manage the reorganization process as they pay for greater skill while trying to economize on low-skill jobs? What problems, if any, will result if internal pay differentials grow too large?

Two empirical methods have become useful in answering these and other questions and we expect them to continue to grow in influence in personnel economics. First, studies of single firms, often involving a field experiment, can provide precise analysis of the effects of various human resource policies. This has proven effective in studying incentives, team-based production, and the role of jobs, despite the lack of generalizability of these studies. Well-crafted future studies (and perhaps experiments) can broaden the value of this method to selection, the wage/benefit trade-off, the use of subjective performance evaluation, training, and other areas.

The other method is the exploitation of employer-employee datasets, which have become much more prevalent in recent years. ${ }^{43}$ These data can provide rich time series detail about firms' pay structure, growth, employee tenure, etc. The lack of detail on firms' human resources

\footnotetext{
${ }^{43}$ See Abowd, Kramarz, and Margolis (1999) for a recent survey of some of the data and some of the papers that have used them. Also, see Lazear and Shaw (2007) for a series of studies using datasets of this sort from a variety of countries to analyze pay and turnover patterns within and across firms.
} 
practices makes it challenging to frame an economic question in a manner that can be addressed across the whole dataset. But careful modeling and/or focusing on certain industries or types of workers often helps make the exercise manageable.

Personnel economics has come a long way in the last few decades. We have learned a great deal about the underlying economics of human resource policies. But, through the methods and ideas we have just mentioned, as well as others we have overlooked or that have not yet arisen, we believe there will be much more learned in the next few decades. 


\section{References}

Abowd, John M., and Francis Kramarz, 1999. "The Analysis of Labor Markets Using Matched Employer-Employee Data," in Handbook of Labor Economics, Vol. III, eds. Orley C. Ashenfelter and David Card. Amsterdam: North Holland.

Acemoglu, Daron and Joshua D. Angrist, 2001. "Consequences of Employment Protection? The Case of the Americans with Disabilities Act," Journal of Political Economy, 109(5), 915957.

Acemoglu, Daron and Jorn-Steffen Pischke, 1998. "Why Do Firms Train? Theory and Evidence," Quarterly Journal of Economics, 113(1), 79-119.

Acemoglu, Daron and Jorn-Steffen Pischke, 1999. "The Structure of Wages and Investment in General Training," Journal of Political Economy, 107(3), 539-572.

Adams, Christopher, 2005, “Agent Discretion, Adverse Selection and the Risk-Incentive TradeOff," Working Paper, Federal Trade Commission.

Aggarwal, Rajesh K. and Andrew A. Samwick, 1999. "The Other Side of the Trade-off: The Impact of Risk on Executive Compensation," Journal of Political Economy, 107(1), 65-105.

Aggarwal, Rajesh K. and Andrew A. Samwick, 1999. "Executive Compensation, Strategic Competition, and Relative Performance Evaluation: Theory and Evidence," Journal of Finance, 54(6), 1999-2043.

Akerlof, George A., 1970. “The Market for 'Lemons': Quality Uncertainty and the Market Mechanism," Quarterly Journal of Economics, 84(3), 488-500.

Altonji, Joseph G. and Charles R. Pierret, 2001. "Employer learning and statistical discrimination," Quarterly Journal of Economics, 116(1), 313-350.

Andersson, Fredrik, Matthew Freedman, John C. Haltiwanger, Julia Lane, and Kathryn Shaw, 2006, "Reaching for the Stars: Who Pays for Talent in Innovative Industries?" NBER Working Paper \#12,435.

Antle, Rick and Abbie Smith, 1986. "An Empirical Investigation of the Relative Performance Evaluation of Corporate Executives," Journal of Accounting Research, 24(1), 1-39.

Antos, Joseph R., and Sherwin Rosen. 1975. "Discrimination in the Market for Teachers," Journal of Econometrics 2 (May), 123-150.

Asch, Beth J., 1990. "Do incentives matter? The case of Navy recruiters," Industrial and Labor Relations Review, 43(3), 89S-106S.

Autor, David H., 2001. "Why Do Temporary Help Firms Provide Free General Skills Training?" Quarterly Journal of Economics, 116(4), 1409-1448. 
Autor, David H., John J. Donohue, and Stewart J. Schwab, 2006. "The Costs of WrongfulDischarge Laws," Review of Economics and Statistics, 88(2), 211-231.

Backes-Gellner, Uschi and Johannes Mure, 2005. "The Skill-Weights Approach on Firm Specific Human Capital: Empirical Results for Germany," working paper, University of Zurich.

Baker, George, 1992. "Incentive Measures and Performance Measurement," Journal of Political Economy, 100, 598-614.

Baker, George P., Robert Gibbons, and Kevin J. Murphy, 1994. "Subjective Performance Measures in Optimal Incentive Contracts," Quarterly Journal of Economics, 109, 1125-1156.

Baker, George P., Michael Gibbs, and Bengt Holmstrom, 1994. "The Wage Policy of a Firm," Quarterly Journal of Economics, 109(4), 921-955.

Bandiera, Oriana, Iwan Barankay, and Imran Rasul, 2006, "Social Connections and Incentives in the Workplace: Evidence from Personnel Data," working paper, London School of Economics.

Bandiera, Oriana, Iwan Barankay, and Imran Rasul, 2007, "Incentives for Managers and Inequality Among Workers: Evidence from a Firm-Level Experiment," Quarterly Journal of Economics, forthcoming.

Barro, Jason R. and Robert J. Barro, 1990. "Pay, Performance, and Turnover of Bank CEOs," Journal of Labor Economics, 8(4), 448-481.

Becker, Gary S., 1964. Human Capital. New York: Columbia University Press.

Bénabou, Roland and Jean Tirole, 2003. "Intrinsic and Extrinsic Motivation," Review of Economic Studies, 70(244), 489-520.

Bergman, Nittai K. and Dirk Jenter, 2007, "Employee Sentiment and Stock Option Compensation," Journal of Financial Economics, 84(3), 667-712.

Bergson, Abram. 1978. "Managerial Risks and Rewards in Public Enterprises," Journal of Comparative Economics, 2, 211-25.

Bernhardt, Dan, 1995, "Strategic Promotion and Compensation," Review of Economic Studies, $62: 2,315-339$.

Bertrand, M. and S. Mullainathan, 2001. “Are CEO's Rewarded for Luck? The Ones without Principals Are," Quartery Journal of Economics, 116(3), 901-932.

Black, Sandra E. and Lisa M. Lynch, 2001. "How to Compete: The Impact of Workplace Practices and Information Technology on Productivity," Review of Economics and Statistics, 83(3), 434-445. 
Bloom, Nick and John Van Reenan, 2007, "Measuring and Explaining Management Practices Across Firms and Countries," Quarterly Journal of Economics, forthcoming.

Bollinger, Christopher R. and Julie Hotchkiss, 2003. "The Upside Potential of Hiring Risky Workers: Evidence from the Baseball Industry," Journal of Labor Economics, 21(4), 923944.

Boning, Brent, Casey Ichniowski, and Kathryn Shaw, 2007. "Opportunity Counts: Teams and the Effectiveness of Production Incentives," Journal of Labor Economics, 25(4), 613-650.

Brickley, James A., and Jerold L. Zimmerman, 2001, "Changing Incentives in a Multitask Environment: Evidence from a Top-tier Business School," Journal of Corporate Finance, 7(4), 367-396.

Brown, Charles, 1980. "Equalizing Differences in the Labor Market," Quarterly Journal of Economics, 94(1), 113-134.

Bull, Clive, 1987. "The Existence of Self-Enforcing Implicit Contracts," Quarterly Journal of Economics, 102(1), 147-159.

Bull, Clive, Andrew Schotter; and Keith Weigelt, 1987. "Tournaments and Piece Rates: An Experimental Study,” The Journal of Political Economy, 95(1), 1-33.

Bulow, Jeremy I. and Lawrence H. Summers, 1986. "A Theory of Dual Labor Markets with Application to Industrial Policy, Discrimination, and Keynesian Unemployment," Journal of Labor Economics, 4(3), 376-414

Canziani, Patrizia and Barbara Petrongolo, 2001. "Firing Costs and Stigma: A Theoretical Analysis and Evidence From Microdata," European Economic Review, 45(10), 1877-1906.

Capelli, Peter and David Neumark, 2001. "Do 'High-Performance' Work Practices Improve Establishment-Level Outcomes?” Industrial and Labor Relations Review, 54(4), 737-775.

Capelli, Peter and Kevin Chauvin, 1991. "An Interplant Test of the Efficiency Wage Hypothesis," Quarterly Journal of Economics, 106, 769- 87.

Chan, William, 1996. "External Recruitment versus Internal Promotion," Journal of Labor Economics, 14(4), 555-570.

Cheung, Steven N. S. 1969. The Theory of Share Tenancy: With Special Application to Asian Agriculture and the First Phase of Taiwan Land Reform. Chicago: University of Chicago Press.

Chevalier, Judith \& Ellison, Glenn, 1997. "Risk Taking by Mutual Funds as a Response to Incentives," Journal of Political Economy, 105(6), 1167-1200.

Chevalier, Judith and Glenn Ellison, "Career Concerns of Mutual Fund Managers," The Quarterly Journal of Economics, 114(2), 389-432. 
Courty, Pascal; and Gerald Marschke, 2004. "An Empirical Investigation of Gaming Responses to Explicit Performance Incentives," Journal of Labor Economics, 22(1), 23-56.

Cremer, Jacques, 1986. "Cooperation in Ongoing Organizations," The Quarterly Journal of Economics, 101(1), 33-50.

Deci, Edward L., Richard Koestner, and Richard M. Ryan. 1999. "A Meta-Analytic Review of Experiments Examining the Effects of Extrinsic Rewards on Intrinsic Motivation," Psychological Bulletin, 125(6), 627-668.

Deleire, Thomas, 2000. "The Wage and Employment Effects of the Americans with Disabilities Act," The Journal of Human Resources, 35(4), 693-715.

Dertouzos, James N. and Lynn A. Karoly, Labor-Market Responses to Employer Liability, Santa Monica: RAND Corporation, 1940.

DeVaro, Jed, 2006, "Internal Promotion Competitions in Firms," RAND Journal of Economics, $37(3), 521-542$.

DeVaro, Jed and Fidan A. Kurtulus. 2006. "An Empirical Analysis of Risk, Incentives, and the Delegation of Worker Authority," Working Paper, Cornell University.

DeVaro, Jed and Michael Waldman. 2006. "The Signaling Role of Promotions: Further Theory and Empirical Evidence," Working Paper, Cornell University.

Drago, Robert and Gerald T. Garvey, 1998. "Incentives for Helping on the Job: Theory and Evidence,” Journal of Labor Economics, 16(1), 1-25.

Dranove, David Daniel Kessler, Mark McClellan, and Mark Satterthwaite, 2003. "Is More Information Better? The Effects of 'Report Cards' on Health Care Providers", Journal of Political Economy, 111(3), 555-588.

Duflo, Esther, and Rema Hanna, 2005. "Monitoring Works: Getting Teachers to Come to School," NBER Working Paper, no. 11880.

Dye, Ronald A., 1984. “The Trouble with Tournaments,” Economic Inquiry, 22(1), 147-150.

Ehrenberg, Ronald G. 1980. "Retirement System Characteristics and Compensating Wage Differentials in the Public Sector," Industrial and Labor Relations Review, 33(4), 470-483.

Ehrenberg, Ronald G. and Michael L. Bognanno, 1990. “Do Tournaments Have Incentive Effects?” The Journal of Political Economy, 98(6), 1307-1324.

Fairburn, James A. and James M. Malcomson, 2001. "Performance, Promotion, and the Peter Principle," Review of Economic Studies, 68(1), 45-66.

Falk, Armin and Andrea Ichino, 2006, "Clean Evidence on Peer Effects," Journal of Labor Economics, 24(1), 39-57. 
Fama, E., 1980. "Agency Problems and the Theory of the Firm," Journal of Political Economy, 88(2), 288-307.

Farber, Henry, 2005a. "What Do We Know About Job Loss in the United States?" Working Paper \#498, Industrial Relations Section, Princeton University.

Farber, Henry and Robert Gibbons, 1996. "Learning and Wage Dynamics," Quarterly Journal of Economics, 111(4), 1007-1047.

Fernie, Sue and David Metcalf, 1999. "It's Not What You Pay it's the Way that You Pay it and that's What Gets Results: Jockeys' Pay and Performance," LABOUR: Review of Labour Economics \& Industrial Relations, 13(2), 385-411.

Fershtman, Chaim and Kenneth L. Judd, 1987. "Equilibrium Incentives in Oligopoly," The American_Economic Review, 77(5), 927-940.

Flaherty, Colleen N., 2006, "The Effect of Employer-Provided General Training on Turnover: Examination of Tuition Reimbursement Programs," working paper, Stanford University.

Frank, Robert H. 1984. “Are Workers Paid Their Marginal Products?” American Economic Review, 74(4), 549-571.

Freeman, Richard B. and Morris M. Kleiner, 2005. "The Last American Shoe Manufacturers: Changing the Method of Pay to Survive Foreign Competition," Industrial Relations, 44(2), 307-330.

Gant, Jon, Casey Ichniowski and Kathryn Shaw, 2002. "Social Capital and Organizational Change in High-Involvement and Traditional Work Organizations," Journal of Economics \& Management Strategy, 11(2), 289-328.

Gant, Jon, Casey Ichniowski and Kathryn Shaw, 2003. "Working Smarter by Working Together: Connective Capital in the Workplace," Working Paper.

Garicano, Luis, 2000, "Hierarchies and the Organization of Knowledge in Production," Journal of Political Economy, 108(5), 874-904.

Garicano, Luis, and Esteban Rossi-Hansberg. 2006, "Organization and Inequality in a Knowledge Economy," Quarterly Journal Economics, 121(4), 1383-1435.

Garicano, Luis, and Timothy Van Zandt. "Hierarchy," forthcoming in Handbook of Organizational Economics, eds. Robert Gibbons and D. John Roberts. Princeton: Princeton University Press, 2006.

Garvey, Gerald and Todd Milbourn, 2003. "Incentive Compensation When Executives Can Hedge the Market: Evidence of Relative Performance Evaluation in the Cross Section," The Journal of Finance, 58(4), 1557-1582. 
Garvey, Gerald and Todd Milbourn, 2006. "Asymmetric Benchmarking in Compensation: Executives are Rewarded for Good Luck But Not Penalized for Bad," Journal of Financial Economics 82(1), 197-226.

Gaynor, Martin, James Rebitzer and Lowell Taylor, 2004. "Physician Incentives in Health Maintenance Organizations," Journal of Political Economy, 112, 915-931.

Gibbons, Robert. 1987. "Piece-Rate Incentive Schemes," Journal of Labor Economics, 5(4), 413-29.

Gibbons, Robert and Lawrence Katz, 1991. "Layoffs and Lemons," Journal of Labor Economics, 9(4), 351-380.

Gibbons, Robert, Lawrence Katz, Thomas Lemieux and Daniel Parent, 2005. "Comparative Advantage, Learning, and Sectoral Wage Determination," Journal of Labor Economics, 23(4), 681-724.

Gibbons, Robert, and Kevin J. Murphy, 1990, "Relative Performance Evaluation for Chief Executive Officers," Industrial and Labor Relations Review, 43, 30s-51s.

Gibbons, Robert, and Kevin J. Murphy, 1992. "Optimal Incentive Contracts in the Presence of Career Concerns: Theory and Evidence," Journal of Political Economy, 100(3), 468-505.

Gibbons, Robert, and Michael Waldman, 1999. "Careers in Organizations: Theory and Evidence," in Handbook of Labor Economics, Vol. III, eds. Orley C. Ashenfelter and David Card. Amsterdam: North Holland.

Gibbons, Robert, and Michael Waldman. 2006. "Enriching a Theory of Wage and Promotion Dynamics inside Firms," Journal of Labor Economics, 24(1), 59-107.

Gibbs, Michael, and Wallace Hendricks. 2004. "Do Formal Salary Systems Really Matter?" Industrial and Labor Relations Review, 58(1), 71-93.

Green, Jerry R. and Nancy L. Stokey, 1983. "A Comparison of Tournaments and Contracts," Journal of Political Economy, 91(3), 349-364.

Greenwald, Bruce, 1986. "Adverse Selection in the Labor Market," Review of Economic Studies, 53(3), 325-347.

Groves, Theodore, Yongmiao Hong, John McMillan and Barry Naughton, 1994. "Autonomy and Incentives in Chinese State Enterprises," Quarterly Journal of Economics, 109, 183-209.

Gruber, Jonathan, 2000. "Health Insurance and the Labor Market," in Handbook of Health Economics, eds. A.J. Culyer and J.P. Newhouse. Amsterdam: North Holland.

Hallock, Kevin F., 2006. "Layoffs in Large U.S. Firms from the Perspective of Senior Managers," Research in Personnel and Human Resources Management, 25, 137-179. 
Hamermesh, Daniel S., 1999. "Changing Inequality In Markets For Workplace Amenities," Quarterly Journal of Economics, 114(4), 1085-1123.

Hamilton, Barton H., Jack A. Nickerson, and Hideo Owan, 2003. "Team Incentives and Worker Heterogeneity: An Empirical Analysis of the Impact of Teams on Productivity and Participation," Journal of Political Economy, 111(3), 465-497.

Hayes, Rachel M., Paul Oyer, and Scott Schaefer, 2006. "Co-Worker Complementarity and the Stability of Top Management Teams." Journal of Law, Economics, and Organizations, 22, 184-212.

Hayes, Rachel M. and Scott Schaefer, 2000. "Implicit Contracts and the Explanatory Power of Top Executive Compensation for Future Performance." RAND Journal of Economics, 31, 273-293.

Harris, Milton and Bengt Holmstrom, 1982. "A Theory of Wage Dynamics," Review of Economic Studies, 49(3), 315-333.

Healy, Paul M., 1985. "The Effect of Bonus Schemes on Accounting Decisions," Journal of Accounting and Economics, 7, 85-107.

Holmstrom, Bengt, 1979. "Moral Hazard and Observability." Bell Journal of Economics, 10, 7491.

Holmstrom, Bengt, 1982. "Moral Hazard in Teams," Bell Journal of Economics, 13(2), 324-340.

Holmstrom, Bengt, 1999. "Managerial Incentive Problems: A Dynamic Perspective", Review of Economic Studies, 66(1), 169-182.

Holmstrom, Bengt and Paul Milgrom, 1991. "Multitask Principal-Agent Analyses: Incentive Contracts, Asset Ownership, and Job Design." Journal of Law, Economics, and Organization, 7, 24-52.

Ichino, Andrea, and Giovanni Maggi, 2000. "Work Environment and Individual Background: Explaining Regional Differentials in a Large Italian Firm," Quarterly Journal of Economics, 115(3), 1057-1090.

Ichniowski, Casey, Kathryn Shaw, and Giovanna Prennushi, 1997. "The Effects of Human Resource Management Practices on Productivity: A Study of Steel Finishing Lines," American Economic Review, 87(3), 291-313.

Ichniowski, Casey, and Kathryn Shaw, 2007. "Insider Econometrics," forthcoming in Handbook of Organizational Economics, eds. Robert Gibbons and D. John Roberts. Princeton: Princeton University Press.

Jacob, Brian A., and Steven D. Levitt, "Rotten Apples: An Investigation of The Prevalence and Predictors of Teacher Cheating", Quarterly Journal of Economics, 118(3), 843-877. 
Jenter, Dirk and Fadi Kanaan, 2006. "CEO Turnover and Relative Performance Evaluation," NBER Working Paper No. 12068.

Jin, Li, 2002. "CEO compensation, Diversification, and Incentives," Journal of Financial Economics, 66(1), 29-63.

Johnson, D. Gale. 1950. "Resource Allocation under Share Contracts," Journal of Political Economy, 58, 111-23.

Jovanovic, Boyan, 1979. "Job Matching and the Theory of Turnover," Journal of Political Economy, 87(5), 972-990.

Kahn, Charles and Gur Huberman, 1988. "Two-Sided Uncertainty and Up-or-out Contracts," Journal of Labor Economics, 6, 423-444.

Kandel, Eugene and Edward P. Lazear, 1992. "Peer Pressure and Partnerships," Journal of Political Economy, 100(4), 801-817.

Kaplan, Steven N. and Bernadette A. Minton, 2006. "How has CEO Turnover Changed? Increasingly Performance Sensitive Boards and Increasingly Uneasy CEOs," working paper, University of Chicago.

King Jr., Ralph T., 1998, “Levi’s Factory Workers are Assigned to Teams, and Morale Takes a Hit," Wall Street Journal, May 20.

Kletzer, Lori G., 1998. “Job Displacement,” Journal of Economic Perspectives, 12(1), 115-136.

Knoeber, Charles R. and Walter N. Thurman, 1994. "Testing the Theory of Tournaments: An Empirical Analysis of Broiler Production," Journal of Labor Economics, 12(2), 155-179.

Kugler, Adriana D. and Gilles Saint-Paul, 2004. "How Do Firing Costs Affect Worker Flows in a World with Adverse Selection?” Journal of Labor Economics, 22(3), 553-584.

Larkin, Ian, 2007. "The Cost of High-Powered Incentives: Employee Gaming in Enterprise Software Sales," working paper, University of California at Berkeley.

Lazear, Edward P., 1979. "Why is There Mandatory Retirement?" Journal of Political Economy, 87(6), 1261-1284.

Lazear, Edward P., 1986a. "Salaries and Piece Rates,” Journal of Business, 59(3), 405-431.

Lazear, Edward P., 1986b. "Retirement from the Labor Force," in Handbook of Labor Economics, eds. Orley C. Ashenfelter and Richard Layard. Amsterdam: North Holland.

Lazear, Edward P., 1986c. "Raids and Offer Matching," Research in Labor Economics, 8, 141165.

Lazear, Edward P., 1989. "Pay Equality and Industrial Politics," Journal of Political Economy, 97(3), 561-580. 
Lazear, Edward P., 1990. "Job Security Provisions and Employment," Quarterly Journal of Economics, 105(3), 699-726.

Lazear, Edward P. 1992. "The Job as a Concept," in Performance Measurement and Incentive Compensation, ed. William J. Bruns, Jr. Cambridge: Harvard Business School Press.

Lazear, Edward P. 1998. "Hiring Risky Workers," in Internal Labour Market, Incentives, and Employment, eds. Isao Ohashi and Toshiaki Tachibanki. New York: St. Martin's Press.

Lazear, Edward P. 1999. "Personnel Economics: Past Lessons and Future Directions," Journal of Labor Economics, 17(2), 199-236.

Lazear, Edward P., 2000a, "Performance Pay and Productivity," American Economic Review, 90(5), 1346-1361.

Lazear, Edward P., 2000b, "The Future of Personnel Economics," 110, Economic Journal, F61139.

Lazear, Edward P., 2004a. "Firm-Specific Human Capital: A Skill-Weights Approach,” NBER Working Paper 9679.

Lazear, Edward P., 2004b. "The Peter Principle: A Theory of Decline," Journal of Political Economy, 112(1), S141-S163.

Lazear, Edward P. 2005. "Output-Based Pay: Incentives, Retention, or Sorting?" Research in Labor Economics, 23, 1-25.

Lazear, Edward P., 2006. "Speeding, Terrorism, and Teaching to the Test," Quarterly Journal of Economics, 121(3), 1029-1061.

Lazear, Edward P. and Sherwin Rosen. 1981. "Rank Order Tournaments as Optimum Contracts," Journal of Political Economy, 89(5), 841-864.

Lazear, Edward P. and Kathryn Shaw, 2007. An International Comparison of the Structure of Wages, Boston: NBER.

Levin, Jonathan, and Steven Tadelis, 2005, "Profit Sharing and the Role of Professional Partnerships," Quarterly Journal of Economics, 120(1), 131-171.

Lluis, Stephanie, 2005. "The Role of Comparative Advantage and Learning in Wage Dynamics and Intrafirm Mobility: Evidence from Germany," Journal of Labor Economics, 23(4), 725768.

Lucas, Robert E., Jr., 1978, "On the Size Distribution of Business Firms," Bell Journal of Economics, 9(2), 508-523. 
Lumsdaine Robin and Olivia Mitchell, 1999. "New Developments in the Economic Analysis of Retirement," in Handbook of Labor Economics, eds. Orley C. Ashenfelter and David Card. Amsterdam: North Holland.

MacLeod, W. Bentley and James M. Malcomson. 1989. "Implicit Contracts, Inventive Compatibility, and Involuntary Unemployment," Econometrica, 57(2), 447-480.

MacLeod, W. Bentley, 2003. "On Optimal Contracting with Subjective Evaluation," American Economic Review, 93(1), 216-240.

Malcomson, James M., 1999. "Individual Employment Contracts," in Handbook of Labor Economics, Vol. III, eds. Orley C. Ashenfelter and David Card. Amsterdam: North Holland.

Manne, Henry G., 1965. "Mergers and the Market for Corporate Control," Journal of Political Economy, 73(2), 110-120.

Marino, Anthony M. and Jan Zabojnik, 2007. "Work-Related Perks, Agency Problems, and Optimal Incentive Contracts," working paper, USC Marshall School.

Marshall, Alfred, The Principles of Economics, London: MacMillan, 1890.

Mas, Alexandre and Enrico Moretti, 2006, "Peers at Work," NBER Working Paper \#12,508.

McCall, Brian, 1990. “Occupational Matching: A Test of Sorts,” Journal of Political Economy, 98(1), 45-69.

Meyer, Margaret, Paul R. Milgrom, and D. John Roberts, 1992. "Organizational Prospects, Influence Costs, and Ownership Changes," Journal of Economics and Management Strategy, $1(1), 9-35$.

Milgrom, Paul and Sharon Oster, 1987. "Job Discrimination, Market Forces, and the Invisibility Hypothesis," The Quarterly Journal of Economics, 102(3), 453-476.

Milgrom, Paul R. and D. John Roberts, 1988. “An Economic Approach to Influence Activities in Organizations,” American Journal of Sociology, 94(supplement), S154-S179.

Milgrom, Paul and John Roberts, 1990. "The Economics of Modern Manufacturing: Technology, Strategy, and Organization," American Economic Review, 80(3), 511-528.

Miller, Robert A., 1984. "Job Matching and Occupational Choice," Journal of Political Economy, 92(6), 1086-1120.

Mirrlees, James, 1974. "Notes on Welfare Economics, Information and Uncertainty," in Essays in Equilibrium Behavior under Uncertainty, eds. M. Balch, D. McFadden, and S. Wu, Amsterdam: North Holland.

Murphy, Kevin J., 1999. "Executive Compensation,” in Handbook of Labor Economics, Vol. III, eds. Orley C. Ashenfelter and David Card. Amsterdam: North Holland. 
Murphy, Kevin J., 2000. "Performance Standards in Incentive Contracts," Journal of Accounting and Economics, 30, 245-278.

Nagin, Daniel S., James B. Rebitzer, Seth Sanders, and Lowell J. Taylor, 2002. "Monitoring, Motivation, and Management: The Determinants of Opportunistic Behavior in a Field Experiment," American Economic Review, 92(4), 850-873.

Nalebuff, Barry J. and Joseph E. Stiglitz, 1983. "Prizes and Incentives Towards a General Theory of Compensation and Competition," Bell Journal of Economy, 14(1), 21-43.

Olson, Craig A., 2002. "Do Workers Accept Lower Wages in Exchange for Health Benefits?" Journal of Labor Economics, 20(2), S91-S115.

Oyer, Paul, 1998. "Fiscal Year Ends and Non-Linear Incentive Contracts: The Effect on Business Seasonality," Quarterly Journal of Economics, 113, 149-185.

Oyer, Paul, 2004. "Why Do Firms Use Incentives That Have No Incentive Effects?" Journal of Finance, 59, 1619-1649.

Oyer, Paul, 2008. "Salary or Benefits?" Research in Labor Economics, forthcoming.

Oyer, Paul, and Scott Schaefer, 2000. "Layoffs and Litigation," Rand Journal of Economics, 31(2), 345-358.

Oyer, Paul, and Scott Schaefer, 2002. "Litigation Costs and Returns to Experience," American Economic Review, 92(3), 683-705.

Oyer, Paul, and Scott Schaefer, 2005. "Why Do Some Firms Give Stock Options To All Employees?: An Empirical Examination of Alternative Theories," Journal of Financial Economics, 76, 99-133.

Oyer, Paul, and Scott Schaefer, 2007. "Personnel-Economic Geography: Evidence from Large US Law Firms," working paper, Stanford University Graduate School of Business.

Prendergast, Canice, 1993. "The Role of Promotion in Inducing Specific Human Capital Acquistion,” The Quarterly Journal of Economics, 108(2), 523-534.

Prendergast, Canice, 1999, "The Provision of Incentives in Firms," Journal of Economic Literature, 37(1), 7-63.

Prendergast, Canice, 2000. "What Trade-Off of Risk and Incentives?" American Economic Review, 90(2), 421-425.

Prendergast, Canice, 2002a. "The Tenuous Trade-Off between Risk and Incentives," Journal of Political Economy, 110(5), 1071-1102.

Prendergast, Canice, 2002b. "Uncertainty and Incentives," Journal of Labor Economics, 20(2), S115-S137. 
Prendergast, Canice, 2007. "The Motivation and Bias of Bureaucrats", American Economic Review, forthcoming.

Prendergast, Canice, and Robert Topel, 1996. "Favoritism in Organizations", Journal of Political Economy, 104: 958-978.

Rajan, Raghuram G. and Julie Wulf, 2006, “Are Perks Purely Managerial Excess?”, Journal of Financial Economics, 79(1), 1-33.

Rosen, Sherwin, 1974. "Hedonic Methods and Implicit Markets: Product Differentiation in Pure Competition," Journal of Political Economy, 82(1), 34-55.

Rosen, Sherwin, 1978. "Substitution and Division of Labour," Economica, 45(179), 235-250.

Rosen, Sherwin, 1982. "Authority, Control, and the Distribution of Earnings," Bell Journal of Economics, 13(2), 311-323.

Rosen, Sherwin, 1986. "The Theory of Equalizing Differences," in Handbook of Labor Economics, eds. Orley C. Ashenfelter and Richard Layard. Amsterdam: North Holland.

Ross, Stephen A. 1973. "The Economic Theory of Agency: The Principal's Problem," American Economic Review, 63(2), 134-39.

Salop, Joanne and Steven Salop, 1976. "Self-Selection and Turnover in the Labor Market," Quarterly Journal of Economics, 90(4), 619-627.

Sattinger, Michael, 1993. "Assignment Models of the Distribution of Earnings," Journal of Economic Literature, 31(2), 831-880.

Schaefer, Scott, 1998. "Influence Costs, Structural Inertia, and Organizational Change," Journal of Economics and Management Strategy, 7(2), 237-263.

Shapiro, Carl and Joseph E. Stiglitz, 1984. "Equilibrium Unemployment as a Worker Discipline Device," American Economic Review, 74(3), 433-444.

Shearer, Bruce, 2004. "Piece Rates, Fixed Wages and Incentives: Evidence from a Field Experiment," Review of Economic Studies, 71(2), 513-534.

Song, Younghwan, 2007. "Recall Bias in the Displaced Workers Survey: Are Layoffs Really Lemons?" Labour Economics, 14(3), 325-345.

Spence, Michael, 1973. “Job Market Signaling,” Quarterly Journal of Economics, 87(3), 355374.

Stern, Scott, 2004. “Do Scientists Pay to Be Scientists?” Management Science, 50(6), 835-853.

Stiglitz, Joseph E. 1975. "Incentives, Risk, and Information: Notes Toward a Theory of Hierarchy," Bell Journal of Economics and Management Science, 6, 552-79. 
Thaler, Richard and Sherwin Rosen, 1976. "The Value of Saving a Life: Evidence from the Labor Market," in Household Production and Consumption, ed. Nester Terleckyj. Studies in Income and Wealth no. 40. New York: Columbia University Press (for NBER).

Waldman, Michael, 1984. "Job Assignments, Signalling, and Efficiency," The RAND Journal of Economics, 15(2), 255-267.

Waldman, Michael, 2007. "Connecting Theory and Patterns of Evidence in Internal Labor Markets," forthcoming in Handbook of Organizational Economics, eds. Robert Gibbons and D. John Roberts. Princeton: Princeton University Press.

Woodbury, Stephen A., 1983. "Substitution Between Wage and Nonwage Benefits," American Economic Review, 73(1), 166-182.

Woodcock, Simon D., 2006, “Match Effects,” working paper, Simon Fraser University.

Zabojnik, Jan, 1996. "Pay-Performance Sensitivity and Production Uncertainty," Economic Letters, 53, 291-296. 